\title{
Dengue epidemiology and pathogenesis: images of the future viewed through a mirror of the past
}

\author{
Rashedul Islam¹, Mohammed Salahuddin ${ }^{1}$, Md. Salahuddin Ayubi', Tahmina Hossain ${ }^{1}$, \\ Apurba Majumder ${ }^{2}$, Andrew W. Taylor-Robinson ${ }^{3}$, Abdullah Mahmud-Al-Rafat ${ }^{2,4}$
}

1. Bio-Resources Technology and Industrial Biotechnology Laboratory, Department of Biotechnology and Genetic Engineering, Jahangirnagar University, Dhaka 1342, Bangladesh

2. Biotechnology and Genetic Engineering Discipline, Khulna University, Khulna 9100, Bangladesh

3. School of Medical \& Applied Sciences, Central Queensland University, Rockhampton 4701, Australia

4. Research and Development (R\&D) Department, Incepta Vaccine Limited, Zirabo, Savar, Dhaka 1341, Bangladesh

Every year, millions of individuals throughout the world are seriously affected by dengue virus. The unavailability of a vaccine and of anti-viral drugs has made this mosquito-borne disease a serious health concern. Not only does dengue cause fatalities but it also has a profoundly negative economic impact. In recent decades, extensive research has been performed on epidemiology, vector biology, life cycle, pathogenesis, vaccine development and prevention. Although dengue research is still not at a stage to suggest definite hopes of a cure, encouraging significant advances have provided remarkable progress in the fight against infection. Recent developments indicate that both anti-viral drug and vaccine research should be pursued, in parallel with vector control programs.

KEYWORDS dengue; epidemiology; pathogenesis; dengue vaccine; vector control; anti-viral; animal model

\section{INTRODUCTION}

Dengue has been an issue of increasing public health concern over the past few decades, although the disease achieved a worldwide distribution as long ago as the $18^{\text {th }}$ century, in parallel with industrial expansion (Gubler, 2006). Currently, there is a risk of infection for over 2.5 billion people in the tropics and subtropics and there are 390 million dengue infections reported per year, in about 125 countries worldwide (Bhatt et al., 2013). Dengue virus (DENV) one of the major human pathogenic, mosquito-borne viruses, belongs to the Flaviviridae family. Its four established serotypes (DENV-1 to DENV-4) have

Received: 10 July 2015, Accepted: 7 October 2015

Published online: 20 October 2015

$\triangle$ Correspondence:

Phone: +88-02-7792502-6, Fax: +880-2-8891190

Email: mahmud0907@gmail.com,rafat@inceptavaccine.com

ORCID: 0000-0003-4263-125X been known for many years. Recently, the existence of a fifth serotype has been postulated (Normile, 2013; da Silva Voorham, 2014; Mustafa et al., 2015; Wiwanitkit, 2015). However, unequivocal demonstration of this serotype awaits the recovery of an isolate, and this would need to be characterized using definitive tests to confirm, or conversely to refute, its uniqueness. Although a large number of potential DENV vectors have been considered, evidence shows that Aedes aegypti, the Yellow Fever mosquito, and Aedes albopictus, the Asian tiger mosquito, are the major vectors for dengue transmission. Both species are distributed mainly in the tropical regions of Asia, Africa, Australia, the South Pacific, the Americas and some parts of the Middle East (Higa, 2011). The nature of the disease that is transmitted via the bite of an infectious mosquito varies from a mild self-limiting illness and dengue fever (DF) to severe forms such as dengue hemorrhagic fever (DHF) and dengue shock syndrome (DSS. A combination of the unavailability of effective anti-viral drugs and vaccines with a reliance on symp- 
tomatic treatment has made it a focus of study for the health sector, to be investigated at the most fundamental level. Priorities in dengue research are therefore are directed principally towards the instigation of an efficient management system, implementation of effective vector control, and studies of immunopathogenesis in order to facilitate the development of anti-viral agents and the possible production of multivalent vaccines.

\section{STRUCTURE, ENTRY AND REPLICATION}

Dengue virus comprises an enveloped, positive-strand genome of approximately $11 \mathrm{~kb}$ in length, which encodes three structural and seven non-structural proteins (Ma et al., 2004; Guzman et al., 2010; Rodenhuis-Zybert et al., 2010). The structural proteins include capsid protein (C), membrane protein $(\mathrm{M})$ and envelope protein $(\mathrm{E})$, while the non-structural (NS) proteins are NS1, NS2A, NS2B, NS3, NS4A, NS4B and NS5 (Welsch et al., 2009). Encapsulation of the RNA genome is mediated by multiple copies of $\mathrm{C}$ protein $(11 \mathrm{kDa})$ and results in a viral nucleocapsid, surrounded by a lipid bi-layer in which, remarkably, 180 copies of anchored $\mathrm{M}$ and $\mathrm{E}$ proteins are present (Modis et al., 2005; Nybakken et al., 2006). The processing of a precursor protein (prM) results in a mature $(\mathrm{M})$ protein of approximately $8 \mathrm{kDa}$, which plays a regulatory role in virus fusion, virus entry and $\mathrm{E}$ protein folding (Heinz et al., 2003; Hsieh et al., 2011). Membrane glycoprotein E $(56 \mathrm{kDa})$, consists of three structural domains (domain I, domain II and domain III), which are involved in membrane fusion, virion morphogenesis and receptor binding (Acosta et al., 2014). NS1 (46 kDa) glycoprotein can be categorized in three forms: endoplasmic reticulum (ER)-resident form, membrane-anchored form and secreted form (sNS1). NS1 contains two glycosylation sites, N130 and N207, which are required for viral replication in mosquitoes and neurovirulence in mice (Crabtree et al., 2005; Oliphant et al, 2006). NS2A $(22 \mathrm{kDa})$ is a hydrophobic integral membrane protein which has been found to be involved in RNA replication, whereas NS2B $(14 \mathrm{kDa})$ is an important co-factor for NS3 protease (Huang et al., 2011; Xie et al., 2013). Among all the NS proteins, NS3 $(69 \mathrm{kDa})$ is a well-characterized and multifunctional protein, which consists of a number of catalytic domains. NS3 is involved in nucleoside triphosphatase and helicase functions during viral RNA (vRNA) synthesis (Arias et al., 1993; Falgout et al., 1991; Li et al., 1999). NS4A (16 kDa) is a hydrophobic integral membrane protein, critical for the formation of replication vesicles, whereas NS4B $(30 \mathrm{kDa})$ is a potent suppressor of beta-interferon (IFN- $\beta$ ) and gamma-interferon (IFN- $\gamma$ ) signaling (Miller et al., 2007; Munoz-Jordan et al., 2003; Munoz-Jordan et al., 2005). The most conserved and the largest protein, NS5 $(105 \mathrm{kDa})$, plays a significant role in RNA synthesis and in the blockade of the IFN system (Kroschewski et al., 2008).

Infection with DENV starts when the virus is introduced into the host cells as a result of the vector taking a meal of blood. From various different studies, it has been suggested that cells of hematopoietic origin, e.g., monocytes, macrophages and dendritic cells, are the major target sites for DENV infection, replication and dissemination (Figure 1) (Jessie et al., 2004; Pham et al., 2012). The very early steps in dengue virus entry can be categorized into adsorption and penetration. Several experiments suggested that the most favorable temperature for attachment is between $40{ }^{\circ} \mathrm{C}$ and $37^{\circ} \mathrm{C}$; however, penetration takes place only at $37^{\circ} \mathrm{C}$ (Hung et al., 1999). A number of attachment factors or receptors have been identified, which are responsible for virus entry. In the case of mosquito cells, heat shock protein 70 (Hsp 70), R80, R67 and a $45 \mathrm{kDa}$ protein has shown to interact with DENV (Rodenhuis-Zybert et al., 2010; Yazi et al., 2002). Heparin sulfate Hsp 90, CD14, 78 $\mathrm{kDa}$ glucose-regulated protein - also known as binding immunoglobulin protein - (GRP78/BiP), a 37/67 kDa high-affinity laminin receptor on mammalian cells and C-type lactin receptors of human myeloid cells are all involved in the interaction with DENV particles (Rodenhuis-Zybert et al., 2010). Virus entry starts with a conformational change of $\mathrm{E}$ protein under low $\mathrm{pH}$ conditions (6.5), followed by clathrin-mediated endocytosis (Mercer et al., 2010). Several potent inhibitors such as monoclonal antibodies, heparin and heparin sulfate suppress the penetration process whereas carbohydrate moieties and highly sulfated heparin sulfate promote viral entry (Hung et al., 1999). At this stage the capsid protein releases the viral genome into the cell cytoplasm and subsequently translates it into a single polyprotein in association with ER-derived membranes. This polyprotein is processed further into structural and nonstructural proteins by the action of different cellular and virus-derived proteases (Clyde et al., 2006; Rodenhuis-Zybert et al., 2010; Jain et al., 2014). Once translation and proper folding of virion proteins are completed, NS proteins initiate the replication process using a negative strand intermediate as a template (Clyde et al., 2006). This template is further used for the production of multiple copies of positive-strand vRNA. Afterwards, this newly formed RNA is packaged by the $\mathrm{C}$ protein to form a nucleocapsid and, meanwhile, a heterodimer complex formed by prM and E proteins leaked into the ER lumen is thought to be involved in the virion budding process (Kuhn et al., 2002). The immature virus particles mature by using the secretory pathway, and the trans-Golgi network triggers dissociation of the $\mathrm{prM} / \mathrm{E}$ heterodimers in an acidic environment. These mature virions are now ready to infect cells and are transported out of the cells through exocytosis 
(English et al., 2009; Rodenhuis-Zybert et al., 2010).

\section{EVOLUTION}

Dengue is a historically important disease, which has been known for centuries. Symptoms recorded in a Chinese medical encyclopedia in $992 \mathrm{AD}$ are similar to those of dengue and this is probably the first recorded information relating to dengue (Gubler, 2006). Many documents report that the origin of DENV is Africa. Later, it must have been distributed to many parts of the world by the slave trade (Hirsch, 1883; Smith, 1956). The vector (Ae. aegypti) is also supposed to have originated in Africa (Monath, 1988). However, its origin has been debated and it is now thought to be either Africa or Asia (Wilder-Smith et al., 2008; Murray et al., 2013). Maintenance of all of the serotypes in enzootic forest cycles suggests that these viruses may have evolved by chance in Asia from a progenitor virus that was most likely from Africa (Gubler, 1997). Furthermore, it is believed that DENV may have originated from a forest cycle involving lower primates and canopy-dwelling mosquitoes in the Malay Peninsula (Smith, 1956; Sirisena et al., 2014). Later, the viruses were introduced to villages by humans or mon- keys, who had been exposed to the dengue viruses in the forest, and were propagated there by peri-domestic mosquitoes (Aedes spp.). Finally, the villagers introduced them into urban areas (Gubler, 2004). There are a number of theories relating to the origins of the viruses but they are beyond the scope of this review.

It is possible that different DENV serotypes evolved in taxonomically related mosquito species in different geographical regions. Four DENV serotypes were documented some years ago in a forest cycle in Asia, while only one (DENV-2) was documented in Africa (Rudnick et al., 1986). It is currently thought that DENV probably had an Asian origin, which is supported by serological surveys conducted in rural communities of Malaysia in the early 1950s (Smith, 1956). In any event, by 1800, following increased use of shipping vessels during the expansion of trade routes, DENV was widespread throughout the urban tropical coastal cities of the world (Gubler, 2004; Murray et al., 2013). Transportation of breeding sites for the vector, together with humans, was provided by these ships, which completed the transmission cycle as well as giving a slow but evident introduction of both the virus and the mosquito to coastal destinations around the world (Gubler, 2004). Later on, the incidence of DENV

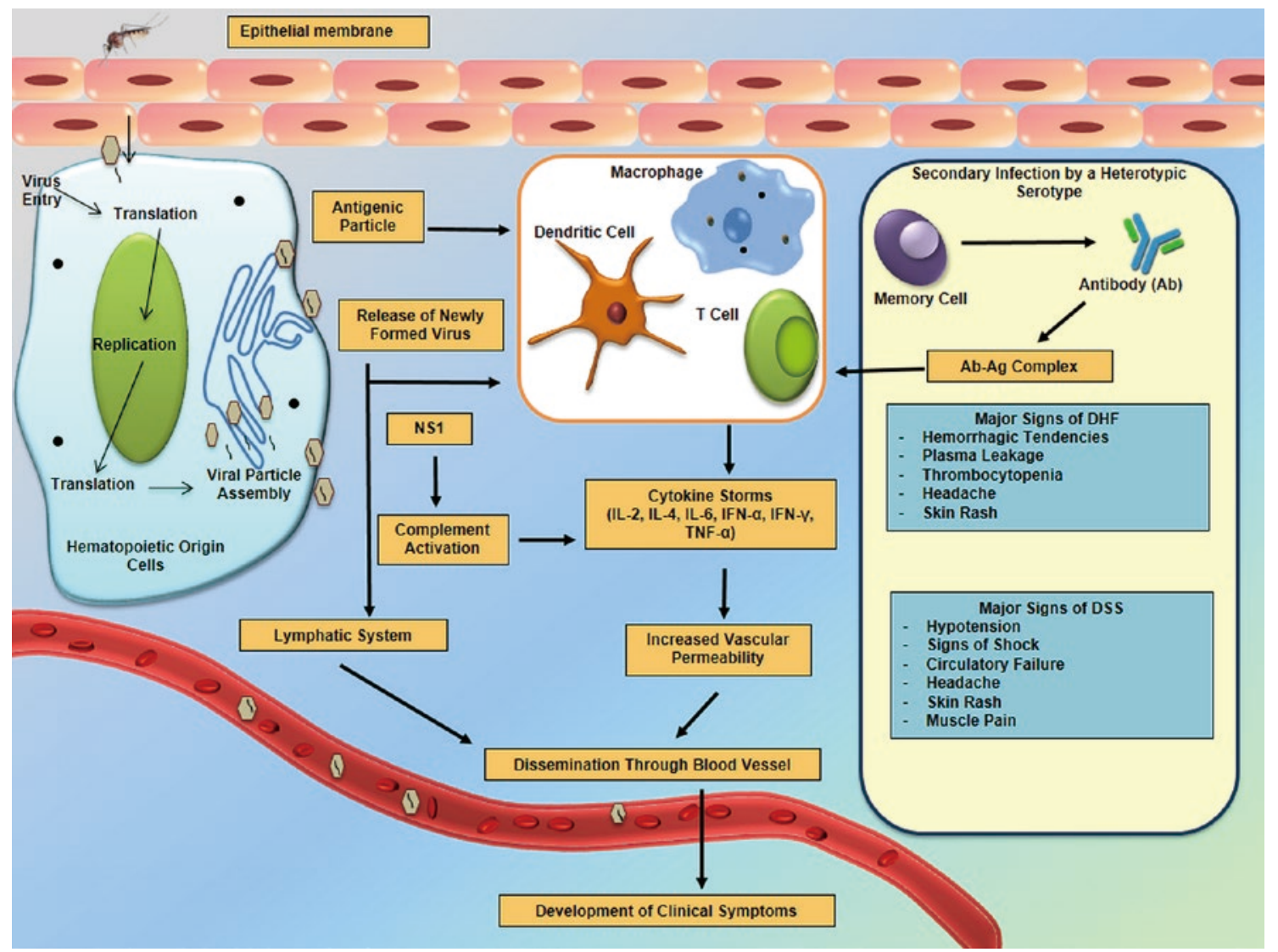

Figure 1. Entry, dissemination and responses of dengue virus in humans. 
increased during World War II when troops started to move within and between countries (Wilder-Smith et al., 2008). By studying evolutionary molecular epidemiology, it was found that the four serotypes of the DENV were clearly organized in well-defined clades. The time to the most recent common ancestor of all of the dengue serotypes, and also the time of the divergence of the DENV-4 lineage, is thought to be 1672 years ago, i.e., in the $4^{\text {th }}$ century AD (Costa et al., 2012). In the second half of the $20^{\text {th }}$ century, dengue emerged as a major public health concern in many tropical and sub-tropical regions around the world.

\section{EPIDEMIOLOGY}

Although the origin of DENV is disputed, most of the studies on epidemiology agree that the widespread geographic distribution was driven by sailing ships and the slave trade (Chen et al., 2011). Ae. aegypti is the predominant epidemic vector of DENV because of its high level of adaptability to the urban environment in tropical cities and its close association with humans. At the same time, Ae. albopictus is considered as a secondary vector because of its better adaptation to peridomestic settings with vegetation; and it prefers to feed on a variety of animals other than humans (Lambrechts et al., 2010; Wilder-Smith et al., 2010). One study suggests that increases in the number of mosquitoes and in mean temperature also facilitate dengue transmission (Halstead, 2008).

It is recognized that host cells become infected by the host being bitten by the vector. Although both human and non-human primates (NHP) serve as hosts of DENV, only humans exhibit clinical symptoms whereas most NHPs are asymptomatic. The primate reservoir hosts in Africa include the African green monkey (Chlorocebus sabaeus), the Patas monkey (Erythrocebus patas) and the Guinea baboon (Papio papio) and closely related species such as the Chacma baboon (Papio ursinus), the olive baboon (Papio anubis) and the yellow baboon (Papio cynocephalus), whereas in Asia the primate reservoir hosts are Southern pig-tailed macaques (Macaca nemestrina), cynomolgus macaques (Macaca fascicularis) and silvered leaf monkeys (Presbytis cristata) and possibly green-mitered leaf monkeys (Presbytis melaphos) (Chen et al., 2011). In America, there is no evidence of a sylvatic DENV transmission cycle, but several NHPs are susceptible to DENV infection including the black-headed spider monkey (Ateles fusciceps), Geoffroy's spider monkey (Ateles geoffroyi), white-headed capuchin ( $\mathrm{Ce}$ bus capucinus), mantled howler (Alouatta palliata), marmoset (Marikina geoffroyi), three-striped night monkey (Aotus trivirgatus) and Central American squirrel monkey (Saimiri orstedii) (Rosen, 1958).

\section{DENGUE AROUND THE WORLD}

\section{Dengue in Asia}

Disruption of ecosystems, increased troop movement, and rapid urbanization after World War II have promoted the wide dissemination of the dengue vector and virus, especially in Asia. Use of water storage containers for domestic purposes, and the presence of discarded war equipment, have all served as ideal breeding habitats for Ae aegypti (Halstead, 2006). By the end of the war, countries (Cambodia, Philippines, Thailand, Vietnam) susceptible to dengue epidemics became hyper-endemic for DENV (Halstead, 2006). Isolation of all the dengue serotypes in the 1940s and 1950s has left a certain amount of confusion regarding the exact time period during which DENV has been present in this area, because they were probably present earlier than this (Gubler, 1997; Sabin, 1952). DHF emerged in Manila (Philippines) in 1954 (Hammon et al., 1960); thereafter, it appeared in Thailand in 1958, while Cambodia, Malaysia, Singapore and Vietnam (Gubler, 2002) all reported the presence of DHF cases in the 1960s. In India, the first virologically proved epidemic occurred in Calcutta and on the Eastern Coast in 1963-1964. DHF began occurring in various parts of India in 1988 (Sarkar et al., 1964; Gupta et al., 2012). Pakistan reported cases of DHF in 1994 in Karachi (Chan et al., 1995). In Bangladesh, DF was documented from the mid-1960s to the mid-1990s, but an outbreak of DHF was reported in 2000 (Rahman et al., 2002). Epidemics in Bhutan (Dorji et al., 2009) and Nepal (Pandey et al., 2004) were reported only in 2004.

Countries to the north of a 30 degree line of latitude are considered to be at low risk for dengue because most of the countries in this zone have not yet reported any cases of dengue (WHO, 2012a). By the end of 2012, according to the $\mathrm{WHO}$, the dengue-risk countries were Bangladesh, Bhutan, Brunei, Cambodia, Hong Kong (China), India, Indonesia, Lao PDR, Macau (China), Malaysia, Myanmar, Nepal, Pakistan, Philippines, Singapore, Sri Lanka, Taiwan (China), Thailand, and Vietnam (WHO, 2012b). It is apparent that the WHO South-East Asia (SEA) Region, which consists of 11 countries (Bangladesh, Bhutan, India, Indonesia, Maldives, Myanmar, Nepal, North Korea, Sri Lanka, Thailand, Timor-Leste), has become hyper-endemic, with regular reporting of dengue cases since the year 2000, except in North Korea. The greatest number of cases $(355,525)$ and deaths $(1,982)$ were recorded during 2010 . Since then, a declining trend has been reported (Dash et al., 2012). Although not all the variables associated with the expansion of areas infected with dengue can be discerned, the major factors highlighted by many studies are population expansion and urbanization. Cummings et al. (2009) have suggested, using mathematical modelling, that the den- 
gue virus spreads at an average speed of 148 kilometres per month in Bangkok and a similar rate of endemic zone expansion was anticipated elsewhere (Cummings et al., 2009).

There is no doubt that dengue is now a worldwide concern; however, about two-thirds of the global population exposed to dengue lives in the Asia-Pacific region (WHO, 2012a). There is a population of 1.3 billion who reside in 10 dengue-endemic countries in SEA, and dengue heads the list for hospitalization and death in children from this region (Dash et al., 2012). Epidemics remain and continue to maintain regular 3-5 year cycles throughout SEA, and the number of reported cases also continues to increase, together with the severity of cases in many member countries (Shepard et al., 2013). A total of 187,333 dengue cases were reported to WHO in 2010 from this region (Ferreira, 2012). The rate of increase of severe dengue is 18 times higher in this region compared to the Americas (WHO, 2012a; Shepard et al., 2013).

The Communicable Disease Threats Report of March, 2014, a weekly bulletin of the European Centre for Disease Prevention and Control (ECDC), reports that Malaysia and Singapore experienced a higher number of cases in 2014 compared to 2013. In February 2014, dengue activity was almost four times higher compared to the same time period of 2013. The recent trend of number of cases has been increasing in Lao PDR. However, in early 2014, the number of cases remains low in Lao PDR and is also lower when compared to 2013. The observed trend, in decreasing order, is: Cambodia, Philippines and Vietnam (ECDC, 2014).

It had been thought that Japan was a dengue risk-free country. Despite this, according to the national casebased surveillance system of Japan, the reported incidence of DENV was 200 in 2010, four times greater than in 2006. In fact, in these cases, the patients were individuals who had returned from endemic countries. However, one of the mosquito vectors for dengue, Ae. albopictus, inhabits Japan and a major outbreak in western Japan occurred between 1942 and 1945. Globalization has always posed a risk of possible outbreaks in Japan (Nakamura et al., 2012).

\section{Dengue in Australia}

In 1873, eight cases of dengue were imported by ship from Mauritius, and this was the first report of dengue in Australia. The first domestic outbreaks probably occurred in Queensland, at Townsville in 1879 and at Rockhampton in 1885 (Lumley et al., 1942). Several epidemics were described during the late $19^{\text {th }}$ century and early $20^{\text {th }}$ century. Besides the northern part of Australia, cases were reported from northern New South Wales and from Western Australia, but not from the more southern areas of the country. Cases from northern New South
Wales were reported for the first time in 1898 , but the epidemic did not extend to the southern part of this state until 1925-1926, when dengue cases were described from Newcastle. Eastern Australia (Brisbane) reported dengue in 1905, whereas Western Australia reported it in 1909-1910. No cases have been reported from Western Australia since the 1940s and the last epidemic activity in the Northern Territory occurred in Darwin in 1955 (McLean et al., 1959; Russell et al., 1984; Mackenzie et al., 1996). Ae. aegypti is the only dengue vector in Australia; it was possibly introduced in the early or mid- $19^{\text {th }}$ century, with the settlement of the tropics and subtropics (Mackenzie et al., 1996). It was widely distributed in the north-eastern coastal areas by the end of the $19^{\text {th }}$ century. Later on, the population of this vector started declining from northern New South Wales and from the western part of Australia because of effective vector control. However, Cairns and Townsville in Queensland, and Darwin in the Northern Territory, are always at risk of a dengue outbreak. The conversion of urban water supplies from household rainwater tanks to a reticulated supply, the change from steam to diesel locomotives, the use of domestic insecticides, the advent of the motor mower, and greater awareness by local health officers, together with public education, have all facilitated a reduction of the Ae. aegypti population throughout Australia (Mackenzie et al., 1996; Ritchie et al., 2013).

After a quarter of a century, Dengue re-appeared in northern Queensland in 1981-1982. DENV-3 was responsible for a previous epidemic in northern Queensland and the Northern Territory in 1955 (Doherty et al., 1967), whereas the later epidemic was the result of DENV-1 (Guard et al., 1984; Kay et al., 1984). Cairns, Thursday Island and Townsville were all affected. Following this, DENV-1 and DENV-2 cases were reported from 1990 to 1993 (Mackenzie et al., 1996). In the most recent Queensland epidemic of 1993, 238 serologically positive cases of DF and one case of DHF were identified. A DENV-2-mediated outbreak with 900 serologically confirmed cases and an additional 950 cases inferred on clinical grounds was recorded in Townsville (population 120,000) and in Charters Towers (population 10,000) (Phillips et al., 1992; Row et al., 1993). A serological study of 1,000 randomly selected residents of Charters Towers suggests that $20 \%$ of the population of this one town were infected with DENV-2 during this outbreak (McBride et al., 1998). Illness because of dengue is most common among travelers who are returning to Australia. In recent years, there were several large and explosive outbreaks in northern Queensland in areas where the dengue vector is present. These events are increasing the degree of concern regarding the risk of local transmission from imported cases. The number and proportion of dengue cases that are acquired overseas are increasing. 
These figures in 2010 and 2011 had increased by $298 \%$ and $155 \%$, respectively, compared to the earlier five year mean figure (Knope et al., 2013). In 2012, these cases acquired overseas were likely to be the highest on record, with an average of 144 cases per month during January to July (Knope et al., 2013). Data for 14 years (19992012) showed that more than half of all cases with a known country of acquisition were acquired in Indonesia (Knope et al., 2013). In Western Australia in 2010 and 2011, more than $80 \%$ of the cases acquired in Indonesia were acquired in Bali and the trend continued into 2012 (Australia Department of Health Western, 2012). A comparison between 2000 and 2011 suggests that travelers returning from Indonesia have an $8.3 \%$ risk of catching dengue compared to all other destinations (Knope et al., 2013). According to the ECDC, Australia experienced a higher number of dengue cases in 2014 than in 2013 (ECDC, 2014).

\section{Dengue in Africa}

Africa has its own history of dengue epidemics. Since the early years of the $19^{\text {th }}$ century, many countries, including Egypt (1887, 1927), Burkina Faso (1925), Senegal (1927-1928), South Africa (1926-1927) and Zanzibar $(1823,1870)$, reported outbreaks of dengue. These cases were confirmed using neutralizing antibody $(\mathrm{Ab})$ testing in the mid-1950s (Gubler et al., 1995; Amarasinghe et al., 2011). Over the last 50 years (1960 to 2010), outbreaks were reported in 15 African countries, with most occurring in East Africa. Nearly 300,000 cases were reported in five large epidemics in Cape Verde (2009), Comoros (1992-1993), Djibouti (1992-1993), Reunion Island (1977-1978) and the Seychelles (1977-1979) (Cornet, 1993; Amarasinghe et al., 2011). Five countries of Northern Africa: (Algeria, Libya, Morocco, Tunisia and Western Sahara), from which the vectors are not yet clearly identified, are considered to be at low risk for dengue (Were, 2012).

DENV was first isolated in Africa, in Nigeria in the 1960s (Carey et al., 1971). All four DENV serotypes were isolated, with DENV-2 reported to cause the most epidemics (Were, 2012). These serotypes were maintained by enzootic cycles between NHP and arboreal mosquitoes (Vasilakis et al., 2007; Guzman et al., 2010). There are other species of Aedes in Africa, which also act as potential vectors, and they are Ae. albopictus, Ae. africanus and Ae. luteocephalus (Were, 2012). One study reported that dengue-infected travelers came more frequently from South-East Asia and South America than from Africa to non-endemic regions of Europe and America (Freedman et al., 2006). Although the enzootic forms of DENV may be less infective in Africa, there is still a potential for endemic forms of the virus to emerge from sylvatic cycles between mosquitoes and NHP (Vas- ilakis et al., 2007). ECDC's weekly bulletin of 10 March 2014 reported that 26 cases of dengue fever had been detected on Mayotte Island, of which eight were acquired locally and the others had been imported. The occurrence of locally acquired cases with no epidemiological link suggests that there is now active circulation in this area (ECDC, 2014).

\section{Dengue in Europe}

Europe is a place relatively safe from dengue, compared to other regions of the world. According to the ECDC, Europe has not experienced a sustained transmission of dengue fever since the 1920s, with the exception of a large outbreak in 2012 (Normile, 2013). This outbreak occurred on the Madeira Islands (Portugal) from October 2012 to March 2013, and resulted in over 2100 cases of dengue fever. In addition, 78 more cases were introduced into 13 other European countries by travelers returning from Madeira. The responsible strain was a DENV-1 serotype (Alves et al., 2013). France and Croatia reported their first cases in 2010. These outbreaks and sporadic occurrences in Europe are to be expected, following the return of infected travelers from an area of infection. Six cases were reported in the United Kingdom, two each in France and Germany, and one in Sweden, all of which originated from Madeira. In addition, eight cases were diagnosed after returning to mainland Portugal.

In concert with climatic and temperature changes in Europe, the occurrence of Ae. aegypti has also increased. Researchers at the Epidemiology and Global Health unit at Umea University, Sweden, claim that there is the potential for future outbreaks because of increasingly favorable living and breeding conditions for the mosquito in Europe. The mosquito vector Ae. albopictus has already established itself in Europe. Although Ae. albopictus is not as competent a vector as Ae. aegypti, several indigenous cases of the disease have been observed in countries such as France and Croatia. Ae. albopictus was reported initially from Albania in 1979 and then from Italy in 1990. After 2005, it spread into other European countries: Belgium, Bulgaria, Germany, Netherlands, Russia, and Serbia, and also Turkey (Medlock et al., 2012). The last outbreak in Madeira has proved that it is not just a theoretical possibility for the disease to appear in Europe. Climate change, including extreme weather with large daily temperature fluctuations, globalization, and immigration into Europe might all be factors driving a relative increase in dengue fever cases. In 2014, there were no autochthonous cases detected (ECDC, 2014).

\section{Dengue in North America}

Dengue is an emerging infectious disease in North America. Guam, Puerto Rico, Samoa and the US Virgin Islands are known as endemic sites for this virus. In 
Puerto Rico, DENV-mediated outbreaks have been reported since 1915 (King, 1917), including an island-wide epidemic in the late 1960s (Tomashek et al., 2009). The first isolation of the virus in Puerto Rico was during a large outbreak in 1963-1964 (only DV-3 was isolated), whereas the first case of DHF was documented in 1975, although multiple cases of DHF did not occur until 1986 (Neff et al., 1967; Tomashek et al., 2009). During the 1960s and early 1970s, an Ae. aegypti eradication campaign began in the Americas, with a view to interrupting DENV transmission. However, efforts aimed at vector surveillance and control measures were not sustained and subsequent re-infestations of mosquitoes were documented, followed by dengue outbreaks in the Caribbean, and in Central and South America (Nathan et al., 2009). The Caribbean, Mexico and Central America are dengue epidemic areas. The basis of locally acquired dengue disease in the USA is travel. Almost all dengue cases reported in the 48 contiguous states of the USA suggested the involvement of travelers or immigrants (Beatty et al., 2005). Locally acquired outbreaks have been described in Hawaii, St. Croix (US Virgin Islands), along the Texas-Mexico border (Mohammed et al., 2010), and in the western part of Florida (CDC, 2010). Both Ae. aegypti (predominant) and the Ae. albopictus mosquitoes are competent vectors and exist within the south-eastern USA (CDC, 2007; Guzman et al., 2010). Ae. aegypti is abundant all year round in Puerto Rico, and in most of the Caribbean basin. A seroepidemiologic study of a unit of US soldiers who had returned from Somalia suggested that $7.7 \%$ of them were infected with dengue (Sharp et al., 1995).

\section{Dengue in South America}

Dengue virus transmission has been reported in most of the countries of this continent. Argentina, Barbados, Brazil, Colombia, Dominican Republic, El Salvador, French Guyana, Peru, Puerto Rico and Venezuela are countries which are highlighted as being endemic for dengue (all four serotypes) (PAHO, 2008; San Martín et al., 2010). Uruguay and continental Chile are the only countries without indigenous transmission in Latin America (San Martín et al., 2010). Evidence of partial interruption of dengue epidemiology could be found during the 1960s and early 1970s. This was because of an Ae. aegypti mosquito eradication campaign designed to prevent yellow fever (Gubler, 1989). However, poor vector surveillance and control measures revealed mosquito re-infestations, and thus introduced DENV-2 in these regions. In the late 1970s and early 1980s, DENV-1 and DENV-4 were introduced into some Latin American and Caribbean countries, causing devastating epidemics (Isturiz et al., 2000). Since then, the region has reported the highest incidence of cases worldwide $(68 \%$ of all cases worldwide from 2000 to 2006), with periodic outbreaks every three to five years. In Cuba in 1981, the first large epidemic of DHF in the region occurred, which included 24,000 cases of DHF, 10,000 cases of DSS and 158 deaths reported during a three month period (Guzman et al., 1984; Gubler, 1989; Isturiz et al., 2000). Massive dengue outbreaks were reported in Brazil in 1986 and 1987 (Fiqueiredo et al., 1990). In 1990, nearly one-quarter of the 300,000 inhabitants of Iquitos, Peru, were reported to have DF, while in Venezuela there were 3,108 cases of DHF, with 78 deaths reported in the same year. The largest epidemic occurred in 2002, with more than one million reported cases (San Martín et al., 2010; Shepard et al., 2011; Cafferata et al., 2013). The average incidence rate of dengue cases reported in these countries from 2000 to 2007 was 71.5 per 100,000 people annually, and this increased in relation to the period from 1990 to 1999 . The average incidence rate of DHF was 1.7 per 100,000 from 2000 to 2007, with 1391 deaths occurring in this period (San Martín et al., 2010). The Southern Cone countries (Argentina, Brazil, Chile, Paraguay and Uruguay) had the majority of cases of dengue in the last decade. From 2001 to 2007, 64.6\% $(2,798,601)$ of all dengue cases in the Americas were reported from this region, of which 6,733 were DHF with a total of 500 deaths. Brazil had the highest number of cases and comprised $98.5 \%$ of the Southern Cone reports. The first three serotypes (DENV-1, DENV-2 and DENV-3) were found to be responsible for dengue in this region. A slight decreasing trend ( $65 \%$ decrease) was recorded up until March 2014 (1,262 cases) in Costa Rica, compared to the same period of 2013. However in other countries, such as Brazil and Honduras, dengue activity has increased.

\section{PATHOGENESIS}

The majority of dengue infections may go unrecognized are they are asymptomatic. Clinical manifestations can range from a mild flu-like syndrome (DF) to the most serious manifestations, such as DHF and DSS (Martina et al., 2009). DF is self-limiting and has an incubation period of 3-15 days. Clinical manifestations of DF are characterized by arthralgia, bone pain, headache, muscle pain, leucopenia, myalgia, retro-orbital pain and skin rash (Guha-Sapir et al., 2005; Zompi et al., 2012). DF is commonly known as 'seven-day fever' because of its persistence for a week, and it is also called 'break bone fever' (Bäck et al., 2013). Secondary infection with a heterotypic serotype triggers antibody-dependent enhancement (ADE), and this results in DHF/DSS with high mortality (Guzman et al., 2000). DHF is the hemorrhagic state of dengue disease and the manifestations include hemorrhagic tendencies, plasma leakages and thrombocytopenia, in addition to the already existing 
symptoms of DF (WHO, 1999). From DHF, some patients may develop DSS, which is the third and most serious clinical manifestation of dengue. Circulatory failure, hypotension, and signs of shock are the major signs of DSS, together with the previously mentioned symptoms (Barniol et al., 2011). In extreme cases, patients experience profound shock, which often results in a high rate of mortality (Rajapakse, 2011). A lack of appropriate animal models is a major hurdle to understanding the pathogenesis of dengue infection (Bente et al., 2006). Although numerous studies have been carried out on different experimental models, the results are still at a relatively early stage.

\section{Response to DENV in humans}

Pathophysiological responses to DENV infection include increased vascular permeability, microvascular bleeding, plasma leakage and reduced functioning of the coagulation cascade (John et al., 2013). In order to establish the infection, three organ systems play a crucial role: the immune system, the liver and the endothelial cell lineage of blood cells (Martina et al., 2009). Epidermal dendritic cells (DCs) and keratinocytes are the primary infection sites, from where the virus later migrates to lymph nodes (Suharti et al., 2002; Limon-Flores et al., 2005). Later, the lymphatic system amplifies and disseminates the infection, and subsequently monocytes and macrophages become infected (Figure 1) (Martina et al., 2009). Several studies suggest that bone marrow, brain, kidney, liver, lungs, lymph nodes, skin, spleen and thymus also contribute to DENV infection persistence (Kangwanpong et al., 1995; Miagostovich et al., 1997; Ramos et al., 1998; Guzman et al., 1999; Jessie et al., 2004; Basilio-de-Oliveira et al., 2005; Gasperino et al., 2007; Limonta et al., 2007; Martina et al., 2009). Upon detection of an antigenic epitope, immune cells, especially the $\mathrm{CD}^{+}$cross-reactive $\mathrm{T}$ cells, are triggered to produce a broad array of antiviral and pro-inflammatory cytokines. As a consequence, these activated cells express increased levels of interleukins (IL-1 $\beta$, IL-2, IL-4, IL-6, IL-7, IL-8, IL-13, IL-18, TGF-1 $\beta$, TNF- $\alpha$ and IFN- $\gamma$ ) and this ultimately produces a "cytokine storm" (Martina et al., 2009; Rothman, 2011; John et al., 2013). Interestingly, despite all of these inflammatory cytokines, a lesser level of IL-10 was found to be expressed. This phenomenon may be an indication of a lack of immune regulation over T-cell-mediated excessive immune response in humans, but the overall mechanism is yet to be elucidated (Martina et al., 2009). Antibody responses to DENV infection are complex. So far, it is apparent that primary infection with one serotype provides a lifelong Ab-dependent immunity against that specific serotype but only transient immunity to other serotypes (Rothman, 2004). Secondary infection with a heterologous serotype will cause Ab-dependent enhancement of infection, which often causes an increased risk of DHF. Infants who are passively immunized by maternal antibodies from a dengue pre-immune mother are at high risk of severe dengue infection (Beltramello et al., 2010; Wahala et al., 2011). The complement system, one of the major components of the immune response, has also been shown to play an important role in dengue pathogenesis. Plasma leakage is evident from the presence of high levels of the activation products of complement $\mathrm{C} 3 \mathrm{a}$ and $\mathrm{C} 5 \mathrm{a}$ (Churdboonchart et al., 1983; Shaio et al., 1992). Results from different research studies indicate that NS1 expressed in infected cells can directly trigger complement activation (Kurosu et al., 2007). The activated C5b-C9 complex may stimulate the cellular response and production of inflammatory cytokines, and in addition this complex could autonomously trigger other local and systemic effects (Avirutnan et al., 2006; Markiewski et al., 2007).

\section{Response to DENV in the mouse model}

In order to understand dengue pathogenesis, the development of a suitable animal model is required. The search for animal models began in the $20^{\text {th }}$ century, when the mouse was thought to be the most appropriatemodel to study pathogenesis (Bente et al., 2006). As immunocompetent mice do not show any clinical symptoms of dengue infection, the development of a suitable mouse model is still not without problems (Yauch et al., 2008). The immunocompromised mouse model AG129 was the first reported experimental model, which has a deficiency in IFN- $\alpha / \beta$ and IFN- $\gamma$ receptor genes (Johnson et al., 1999). Infection with mouse-adapted virus serotypes in this model results first in peripheral replication, and then in vascular leakage, hind-leg paralysis and blindness on day 7, and ultimately in death on day 12 (Johnson et al., 1999; Bente et al., 2006; Zompi et al., 2012). To visualize the pathophysiological events in human cells, another recent approach has been to develop humanized mouse models; however, these still cannot mimic completely the human immune response (Zompi et al., 2012; Akkina, 2013). Due to a deficiency in both B and T cells, severe combined immunodeficient (SCID) mice exhibit a lack of both humoral and cellular responses and these mice may also sustain xeno-grafts (Mosier, 2000; Zompi et al., 2012). Peripheral blood lymphocyte (PBL)-SCID mice did not show any clinical signs when they were infected with DENV-1, whereas non-obese diabetic (NOD)-SCID mice, reconstituted with human $\mathrm{CD} 34^{+}$hematopoietic cells, developed clinical signs of DF as seen in humans (Bente et al., 2005; Bente et al., 2006). However, most of these mouse models developed neurotropic disease such as paralysis, which is not common in human patients (Schlesinger, 1977; Raut et al., 1996). Immunocompetent mice are gerenerally tolerant to dengue virus 
infection and replication, but do not show overt signs of the disease. The replication of viruses in mouse tissues is at such low titers that they are almost undetectable. To overcome this problem, researchers have to use the virus at a very high dose, use mouse-adapted dengue virus strains, or use an intracranial route of inoculation (Bente et al., 2006).

\section{Response to DENV in non-human primate (NHP) models}

Although NHPs are the key hosts of DENV in a sylvatic cycle, they do not usually develop any DENV-associated clinical symptoms (Marchette et al., 1973; Wang et al., 2000). Some studies have suggested that subcutaneous DENV infection is associated with viremia and an $\mathrm{Ab}-$-mediated immune response in some NHPs such as chimpanzees and monkeys (Onlamoon et al., 2010). Infection with a high dose of DENV via the intravenous route in rhesus macaques results in hemorrhagic manifestations, e.g. leukopenia (after primary infection) and increased thrombocytopenia (after secondary, heterologous infection), as seen in humans (Halstead et al., 1973a). In some NHPs a cross-reactive sensitivity against the primary infecting serotype is also observed, as in humans (Kochel et al., 2005; Koraka et al., 2007). Although the results of the use of NHPs in pathogenesis studies is limited, researchers are using these NHP models to investigate ADE (Halstead et al., 1973a; Goncalvez et al., 2007) and to develop drugs and vaccines, as well as for testing drug and vaccine safety and efficacy (Guirakhoo et al., 2002; Blaney et al., 2005; Sun et al., 2006; Chen et al., 2007).

\section{DENV-MOSQUITO INTERACTIONS}

Ae. aegypti is the widespread mosquito vector of dengue virus; hence, it is also important to investigate DENV-mosquito interactions. A detailed understanding of this relationship is critically important to inform a strong vector control strategy. For efficient virus transmission, the size and biological status, density and basic reproduction number of mosquito vectors plays a significant role (Halstead, 2008). Temperature and rainfall both show a positive correlation with vector abundance. Once the virus is disseminated to the salivary glands, the probability of virus transmission depends on the gonotrophic cycle. Temperature has an effect on the length of the gonotrophic cycle and warm temperatures shorten the extrinsic incubation period (EIP) (Yasuno et al., 1970; Pant et al., 1973; Halstead, 2008). Rainfall is also found to have a positive effect on vector abundance (Moore et al., 1978). The dissemination of DENV into the salivary glands is influenced by viral titer and the size of the blood meal taken by the mosquito vector (Gubler, 1976; Rosen et al., 1985). Like other insects, mosquitoes also have an elaborate innate immune system, which can confer protective immunity against a variety of pathogens (Dimopoulos, 2003; Ip, 2005). A recent study shows that the JAK-STAT signalling pathway makes a major contribution to the mosquito's anti-dengue defense (Souza-Neto et al., 2009). Suppression of the JAKSTAT pathway through RNAi depletion of its receptor Domeless (Dome) and the Janus kinase (Hop) increases susceptibility to dengue infection whereas the silenced protein inhibitor of activated STAT- (PIAS)-mediated negative regulation provides resistance to infection (Souza-Neto et al., 2009).

\section{VECTOR CONTROL STRATEGIES}

Although dengue was initially considered to be a neglected tropical disease, it has recently been prioritized by the WHO's Global Strategy for Dengue Prevention and Control, 2012-2020 (WHO, 2012a). The WHO is recommending a policy of Integrated Vector Management (IVM) as a further preventive approach to dengue vector control (WHO, 2012c). IVM is defined as "a rational decision-making process for the optimal use of resources for vector control". This is endorsed by the WHO as a prudent, cost-effective and optimal process for vector control programs (WHO, 2012a). The crucial features of IVM are assistance, social mobilization and legislation, collaboration within the health sector and with other sectors, integrated intervention methods development, evidence-based decision making and capacity building (WHO, 2012c). The basic elements of dengue control under IVM are to develop and deliver different intervention (or combinations of interventions) approaches based on local facilities to increase country-specific vector control capacity in all geographical areas and to implement monitoring and evaluation tools. Sustainable vector control is one technical element of the Global Strategy for Dengue Prevention and Control, 2012-2020. Lack of appropriate therapeutic agents and vaccines, in addition to effective vector control approaches, need to be addressed in order to reduce dengue mortality and morbidity.

New vector control tools aimed at Ae. aegypti population suppression and replacement are currently under investigation. The 'Release of Insects with a Dominant Lethalality' (RIDL) system integrates a novel genetic sexing system for mass rearing of male mosquitoes (Gubler, 1997). In this technology, a lethal gene is incorporated into the eggs of Ae. aegypti through microinjection. Afterwards, the gene is integrated into the mosquito genome. The gene produces toxic compounds in the larval stage that kill the larva. Tetracycline is used in rearing 
the larvae, as well as the mosquito, in the laboratory. This antibiotic inhibits the function of the lethal gene and consequently no toxic compound is produced. This allows the larvae to develop fully into adults. RIDL males are released into the environment to permit them to mate with wild females. Fertilized females will produce eggs that hatch into RIDL gene-carrying larvae. All the RIDL gene-carrying larvae will die at late larval or early pupal stage. The Malaysia Institute for Medical Research (IMR) has conducted this project in three phases: (1) establishment of the transgenic Malaysian strain of Ae. aegypti, (2) simulation release trial inside a field house, and (3) field release in a suitable experimental field site. Currently, IMR is implementing the third phase.

In order to develop a novel vector control strategy, the University of Queensland (Australia) is now leading a project based on the discovery of a naturally occurring intracellular endosymbiotic bacterium, Wolbachia. This study is dedicated to developing a new biological approach for the control of dengue. The strategy is to introduce Wolbachia strains into Ae. aegypti. Different strains of Wolbachia can interfere with the mosquito life cycle by direct blocking of virus transmission, as well as by reducing the expected lifespan. As only aging mosquitoes transmit dengue viruses, this reduction in lifespan of the vector is predicted to reduce dengue transmission. Wolbachia has the ability to spread actively into insect populations without causing any overt infection. It is transmitted between generations via mosquito eggs and invades mosquito populations by inhibiting the reproduction of females that do not carry Wolbachia when mated by Wolbachia infected males, through a phenomenon known as cytoplasmic incompatibility (Gubler et al., 1995).

\section{CURRENT PROGRESS IN VACCINE DEVELOPMENT}

About 100 million people all around the world are infected by DENV annually, which makes it an intensifying global public health concern. However, there are still no specific anti-viral therapies or vaccines against DENV commercially available (WHO, 2012a; Wei et al., 2014). Although disease preventive strategies currently prioritize vector control management, considerable efforts are still in progress towards the development of an effective vaccine (Whitehorn et al., 2010). The first documented initiative to develop a dengue vaccine was over 80 years ago (Simmons et al., 1931). Although these particular approaches did not succeed, Hotta, Sabin, Schlensinger and Wisseman later demonstrated the development of a live attenuated dengue vaccine against the DENV-1 serotype by serial passage in suckling mouse brain (Sabin et al., 1945; Schlesinger et al., 1956; Hotta, 1957; Wisseman et al., 1963). However, these experimental vaccines failed to gain approval for commercial production because of the requirement for time-intensive processes such as 16 successive passages and also failure of the virus to trigger pathogenesis in cotton rats, hamsters, guinea-pigs and rabbits (Guabiraba et al., 2014). Sanofi Pasteur has developed a live attenuated DENV chimeric vaccine, which has recently completed phase III evaluation successfully in Latin America (Sanofi Pasteur, 3rd September, 2014). Nevertheless, there are multiple challenges that hinder the production of an efficacious dengue vaccine. One of the significant challenges is to develop an effective vaccine which shows efficacy against all available DENV serotypes. Another major problem is the lack of a suitable animal model in which candidate vaccines can undergo preclinical evaluation. The potentially detrimental role of immune enhancement in dengue pathogenesis is also a concern for vaccine design. Other challenges for vaccine development are incomplete cross-protection, viral interference, and no validated correlates of immunity (protective or pathological) (Whitehorn et al., 2010; Schmitz et al., 2011). At the present time, several candidate vaccines are in either preclinical development or clinical evaluation, and these offer hope of a successful treatment in future.

Multiple modern technical approaches are being applied to develop new-generation dengue vaccines, which include: recombinant subunit vaccines, DNA vaccines, virus-vectored vaccines in combination with traditional approaches such as a live attenuated vaccine (LAV), and an inactivated vaccine. The dengue vaccine that mimics most closely natural infection is LAV, which can induce long-lasting humoral and cellular immune responses. Important parameters of LAVs include sufficient attenuation, low viremia, low reactogenicity and high immunogenicity (Wilder-Smith et al., 2010). Attenuated DENV vaccine candidates for each serotype were developed by independent passaging in tissue culture cells by investigators at Mahidol University, Bangkok, Thailand and the Walter Reed Army Research Institute team in the USA (Bhamarapravati et al., 2000; Sun et al., 2003). The Mahidol research group also produced tetravalent vaccines which were used in clinical trial phases I and II in Thai adults and children, but a further trial was stopped because of adverse reactogenicity (Sabchareon et al., 2002; Sabchareon et al., 2004; Sanchez et al., 2006). Site-directed mutagenesis is a more cutting-edge technique used to attenuate the viral genome. A deletion of $30 \mathrm{nu}$ cleotides $(\triangle 30)$ in the $3^{\prime}$-untranslated region of DENV-4 was the first demonstration of attenuation, denoted DEN$4 \Delta 30$ (Men et al., 1996), and this subsequently entered phase I clinical trials (McArthur et al., 2008). This attenuation strategy has met with some success for DENV1 and DENV-4, but was less effective with DENV-2 and DENV-3 (Men et al., 1996; Whitehead et al., 2003; 
Blaney et al., 2004; Blaney et al., 2004). A large-scale phase III study of a chimeric tetravalent vaccine produced by Sanofi Pasteur demonstrated that it successfully met the primary endpoint, with an overall vaccine efficacy of $60.8 \%$ effectiveness against all four serotypes. It also stated that, "initial safety data are consistent with the favorable safety profile documented in all previous studies of phase I, II and III" (Sanofi Pasteur, 3rd September, 2014). Various reports of pre-clinical studies stated that the tetravalent vaccine is genetically and phenotypically stable (Barrett et al., 2007; Barban et al., 2007), less neurovirulent than YFV 17D (Vlaycheva et al., 2002), and is also immunogenic in monkeys (Guirakhoo et al., 2004). Inactivated virus vaccines have two major advantages over other types of vaccine. First, there is no possibility of inactivated vaccines reverting to their virulent or pathogenic phenotype, and so they are very safe. Second, it is easy to induce balanced immunogenicity (Whitehead et al., 2007). In mice and rhesus monkeys, an inactivated DENV-2 vaccine has been reported to be immunogenic and protective (Putnak et al., 1996). Researchers at the Pedro Kourí Tropical Medicine Institute (Cuba) have developed several recombinant subunit vaccine candidates in collaboration with the Center for Genetic Engineering and Biotechnology, also in Cuba. EDIII-p64k fusion proteins and EDIII-capsid fusion proteins were expressed in Escherichia coli and evaluated in NHPs (Bernardo et al., 2008; Valdes et al., 2009a; Valdes et al., 2009b; Valdes et al., 2011).

To date, a number of other subunit candidate vaccines have been evaluated in mice (Etemad et al., 2008; Chen et al., 2009; Leng et al., 2009; Leng et al., 2010). The approach of DNA vaccine development consists of a plasmid or plasmids containing dengue genes. A tetravalent DNA vaccine inoculated in mice and monkeys elicited elevated neutralization antibodies successfully. A tetravalent DNA vaccine candidate developed by Inovio Pharmaceuticals consisted of a DNA plasmid vector that expressed a single ORF comprising the EDIII domains of all four DENV serotypes, separated by proteolytic cleavage sites (Ramanathan et al., 2009). Kobe University has developed another DNA vaccine candidate which is composed of a mixture of four plasmid vectors, each of which expresses the prM and E proteins of one dengue serotype (Imoto et al., 2007). The US Centers for Disease Control and Prevention (CDC) has also developed a similar DNA vaccine candidate based on $\mathrm{prM} / \mathrm{E}$ expression (Chang et al., 2003; Purdy et al., 2005). A virus-vectored vaccine is another important and convenient approach to the development of a dengue vaccine. In this regime, various different recombinant live virus vectors, such as adenovirus, alphavirus and vaccinia virus, are used and which express dengue $\mathrm{E}$ protein for further evaluation as dengue vaccine candidates. The International Center for Genetic
Engineering and Biotechnology (India) has developed a virus-vectored dengue vaccine candidate based on the expression of a tetravalent chimeric EDIII fusion protein from a replication-deficient adenovirus vaccine vector (Khanam et al., 2009). Another virus-vectored vaccine approach developed by GenPhar in collaboration with the Naval Medical Research Center (USA) is predicated on expression of DENV prM/E from a replication-deficient complex adenovirus vaccine vector that is capable of accommodating multiple large antigen inserts (Raviprakash et al., 2008). Several other virus-vectored vaccine candidates have been evaluated in both mice and NHPs (White, et al., 2007; Suzuki et al., 2009; Brandler et al., 2010; Halstead et al., 2013; Wan et al., 2013). A further recent approach is to develop a transmission-blocking vaccine that interrupts the DENV life cycle. In malaria, another mosquito-borne disease, Pfs $48 / 45$ shows sufficient potential immunogenicity to be considered for a future vector-based transmission-blocking malaria vaccine (Miura, 2007; Chowdhury et al., 2009). By analogy, for DENV it has been shown that mosGCTL-3 expressed in mosquito tissues has a significant interaction with the DENV-2 surface envelope (E) protein and virions, both in vitro and in vivo. Thus, most GCTLs are considered to be a feasible target for transmission-blocking vaccine development against DENV (Liu et al., 2014). Although no dengue vaccine is available in the marketplace at present, the increasing knowledge of DENV molecular virology, of the pathogenesis of infection, and of host immune mechanisms, are offering valuable insights that should underpin improved vaccine design.

\section{FUTURE IMAGES IN DENGUE RESEARCH}

There is considerable evidence to indicate that the global incidence of dengue will be greater in the years to come (Astrom et al., 2012; Murray et al., 2013). Prevention, cure and vector control are the major strategies to combat dengue. At present, there is a poorly developed curing strategy. Vaccines are still under trial and to date there are no effective antiviral drugs. Therefore, an increased focus should be on prevention and vector control policies. However, there exist various challenges tothe many awareness programs launched in the field regarding vector control and disease prevention. Rapid urbanization, a lack of basic sanitation, and increased intra- and inter-migratory activities have all compounded the dengue problem in most endemic countries. It is also worth considering the potential factors that drive dengue activity, such as viral evolutionary change (through virus genotype switching), climate diversity, industrialization, urbanization and the trade cycle. Another approach is to develop anti-viral therapeutics, but there are problems with this also. The DENV immunopathogenesis mecha- 
nism is still not understood fully, because of a lack of appropriate animal models that can mimic satisfactorily the entirety of immunopathogenic manifestations in humans. Although IFN $-\alpha / \beta$ receptor deficient mice show some potential, they are not yet accepted as an optimal mouse model because of a number of limitations that have been discussed herein. Extensive searches have been carried out for animal modelsthat offer greater validity, and a recent proposal is that the use of immunocompetent animal models may be a possibility (John et al., 2013). A recent study in mice described the anti-DENV therapeutic potential of compound A (CpdA), a dissociated glucocorticoids receptor which has anti-inflammatory effects; this can suppress increased cytokine expression, as well as DENV production (Suttitheptumronga et al., 2013). As immunocompetent animals do not show DENV-mediated clinical symptoms and demonstrate anti-dengue immunity successfully, an immunopathogenesis study of immunocompetent animals may therefore help to shed light on the mechanism anti-dengue protection in this experimental system. Although immunocompetent animals are not considered the best model for the study of pathogenesis, it is not possible at this point to reject as irrelevant to the human condition. The judicious use of selective knockout mouse models may start to reveal the complex interplay between different immune cells and cytokines that contributes to anti-dengue immunity. Dengue research has made exciting progress over the last few decades, yet there is still a long way to go. A sound understanding of the problem, coupled with rigorous hypothesis development and painstaking application of scientific method, holds the key to future success to alleviate the burden of this growing threat to global public health.

\section{ABBREVIATIONS}

ADE: antibody-dependent enhancement; BiP: binding immunoglobulin protein; $\mathrm{C}$ protein: capsid protein; CDC: Centers for Disease Control and Prevention; CD14: cluster of differentiation; DENV: dengue virus; DF: dengue fever; DHF: dengue hemorrhagic fever; DNA: deoxyribonucleic acid; DSS: dengue shock syndrome; E Protein: envelope protein; ECDC: European Centre for Disease Prevention and Control; EIP: extrinsic incubation period; ER: endoplasmic reticulum; GRP78: $78 \mathrm{kDa}$ glucose regulated protein; Hsp: heat shock protein; IFN: interferon; IL: interleukin; IMR: Institute for Medical Research; IVM: integrated vector management; LAV: live attenuated vaccine; M Protein: membrane protein; NOD: non-obese diabetic; NHP non-human primates; NS: non-structural; PBL: peripheral blood lymphocyte; prM: precursor protein; TGF: transforming growth factor; TNF: tumor necrosis factor; RIDL: release of insects with dominant lethality; SCID: severe combined immu- nodeficient; SEA: South-East Asia; vRNA: viral RNA; WHO: World Health Organization.

\section{ACKNOWLEDGMENTS}

We thank Dr. Mohammad Shahedur Rahman, Associate Professor and Chair, Department of Biotechnology and Genetic Engineering, Jahangirnagar University, for his inspirations during the preparation of this manuscript.

\section{COMPLIANCE WITH ETHICS GUIDELINES}

The authors declare no actual or potential conflicts of interest in relation to this article. This article does not contain any studies with human or animal subjects performed by the authors.

\section{REFERENCES}

Acosta EG, Kumar A, Bartenschlager R. 2014. Revisiting dengue virus-host cell interaction: new insights into molecular and cellular virology. Adv Virus Res, 88: 1-109.

Akkina R. 2013. New generation humanized mice for virus research: comparative aspects and future prospects. Virology, 435: $14-28$.

Alves MJ, Fernandes PL, Amaro F, Osorio H, Luz T, Parreira P, Andrade G, Zé-Zé L, Zeller H. 2013. Clinical presentation and laboratory findings for the first autochthonous cases of dengue fever in Madeira island, Portugal, October 2012. Euro Surveill, 18: pii: 20398.

Amarasinghe A, Kuritsky JN, Letson GW, Margolis HS. 2011. Dengue virus infection in Africa. Emerg Infect Dis, 17: 13491354.

Arias CF, Preugschat F, Strauss JH. 1993. Dengue 2 virus NS2B and NS3 form a stable complex that can cleave NS3 within the helicase domain. Virology, 193: 888-899.

Astrom C, Rocklov J, Hales S, Beguin A, Louis V, Sauerborn R. 2012. Potential distribution of dengue fever under scenarios of climate change and economic development. Ecohealth, 9: 448-454.

Australia Department of Health Western. 2012. Bali travel behind spike in dengue fever. Disease Watch, 16.

Avirutnan P, Punyadee N, Noisakran S, Komoltri C, Thiemmeca S, Auethavornanan K, Jairungsri A, Kanlaya R, Tangthawornchaikul N, Puttikhunt C, Pattanakitsakul SN, Yenchitsomanus PT, Mongkolsapaya J, Kasinrerk W, Sittisombut N, Husmann M, Blettner M, Vasanawathana S, Bhakdi S, Malasit P. 2006. Vascular leakage in severe dengue virus infections: a potential role for the nonstructural viral protein NS1 and complement. J Infect Dis, 193: 1078-1088.

Bäck AT and Lundkvist Å. 2013. Dengue viruses: an overview. Infect Ecol Epidemiol, 3: 10.3402/iee.v3i0.19839.

Barban V, Girerd Y, Aguirre M, Gulia S, Petiard F, Riou P, Barrere B, Lang J. 2007. High stability of yellow fever 17D-204 vaccine: a 12-year retrospective analysis of large-scale production. Vaccine, 25: 2941-2950.

Barniol J, Gaczkowski R, Barbato EV, da Cunha RV, Salgado D, Martinez E, Segarra CS, Pleites Sandoval EB, Mishra A, Laksono IS, Lum LC, Martínez JG, Núnez A, Balsameda A, Allende I, Ramírez G, Dimaano E, Thomacheck K, Akbar NA,Ooi EE, Villegas E, Hien TT, Farrar J, Horstick O, Kroeger 
A, Jaenisch T. 2011. Usefulness and applicability of the revised dengue case classification by disease: Multi-centre study in 18 countries. BMC Infect Dis, 11: 106.

Basilio-de-Oliveira CA, Aguiar GR, Baldanza MS, Barth OM, Eyer-Silva WA, Paes MV. 2005. Pathologic study of a fatal case of dengue-3 virus infection in Rio de Janeiro, Brazil. Braz J Infect Dis, 9: 341-347.

Beltramello M, Williams KL, Simmons CP, Macagno A, Simonelli L, Quyen NT, Sukupolvi-Petty S, Navarro-Sanchez E, Young PR, de Silva AM, Rey FA, Varani L, Whitehead SS, Diamond MS, Harris E, Lanzavecchia A, Sallusto F. 2010. The human immune response to Dengue virus is dominated by highly cross-reactive antibodies endowed with neutralizing and enhancing activity. Cell Host Microbe, 8: 271-283.

Barrett AD, Monath TP, Barban V, Niedrig M, Teuwen DE. 2007. 17D yellow fever vaccines: new insights. A report of a workshop held during the World Congress on medicine and health in the tropics, Marseille, France, Monday 12 September 2005. Vaccine, 25: 2758-2765.

Beatty ME, Vorndam V, Hunsperger EA, Muñoz JL, Clark GG. 2005. Travel-associated dengue infections - United States, 20012004. Morbidity and Mortality Weekly Report (MMWR), 54: 556-558.

Bente DA, Melkus MW, Garcia JV, Rico-Hesse R. 2005. Dengue fever in humanized NOD/SCID mice. J Virol, 79: 13797-13799.

Bente DA, Rico-Hesse R. 2006. Models of dengue virus infection. Drug Discov Today, 3: 97-103.

Bernardo L, Izquierdo A, Alvarez M, Rosario D, Prado I, Lopez C, et al. 2008. Immunogenicity and protective efficacy of a recombinant fusion protein containing the domain III of the dengue 1 envelope protein in non-human primates. Antiviral Res, 80: 194-199.

Bhamarapravati N, Sutee Y. 2000. Live attenuated tetravalent dengue vaccine. Vaccine, 18: 44-47.

Bhatt S, Gething PW, Brady OJ, Messina JP, Farlow AW, Moyes CL, Drake JM, Brownstein JS, Hoen A G, Sankoh O, Myers MF, George DB, Jaenisch T, Wint GRW, Simmons CP, Scott TW, Farrar JF, Hay SI. 2013. The global distribution and burden of dengue. Nature, 496: 504-507

Blaney JE Jr, Hanson CT, Hanley KA, Murphy BR, Whitehead SS. 2004. Vaccine candidates derived from a novel infectious cDNA clone of an American genotype dengue virus type 2. BMC Infect Dis, 4: 39.

Blaney JE Jr, Hanson CT, Firestone CY, Hanley KA, Murphy BR, Whitehead SS. 2004. Genetically modified, live attenuated dengue virus type 3 vaccine candidates. Am J Trop Med Hyg, 71: 811-821.

Blaney JE, Jr Matro JM, Murphy BR, Whitehead SS. 2005. Recombinant, live-attenuated tetravalent dengue virus vaccine formulations induce a balanced, broad, and protective neutralizing antibody response against each of the four serotypes in rhesus monkeys. J Virol, 79: 5516-5528.

Brandler S, Ruffie C, Najburg V, Frenkiel MP, Bedouelle H, Despres P, Tangy F. 2010. Pediatric measles vaccine expressing a dengue tetravalent antigen elicits neutralizing antibodies against all four dengue viruses. Vaccine, 28: 6730-6739.

Cafferata ML, Bardach A, Rey-Ares L, Alcaraz A, Cormick G, Gibbons L, Romano M, Cesaroni S, Ruvinsky S. 2013. Dengue epidemiology and burden of disease in Latin America and the Caribbean: a systematic review of the literature and meta-analysis. Value in Health Regional Issues, 2: 347-356.

Carey DE, Causey OR, Reddy S, Cooke AR. 1971. Dengue viruses from febrile patients in Nigeria, 1964-1968. Lancet, 1: 105-106.

CDC. 2007. Dengue hemorrhagic fever-U.S.- Mexico border,
2005. MMWR Morb Mortal Wkly Rep, 56: 785-789.

CDC. 2010. Locally acquired Dengue-Key West, Florida, 20092010. MMWR Morb Mortal Wkly Rep, 59: 577-581.

Chan YC, Salahuddin NI, Khan J, Tan HC, Seah CL, Li J, Chow VT. 1995. Dengue haemorrhagic fever outbreak in Karachi, Pakistan, 1994. Trans R Soc Trop Med Hyg, 89: 619-620.

Chang GJ, Hunt AR, Holmes DA, Springfield T, Chiueh TS, Roehrig JT, Gubler DJ. 2003. Enhancing biosynthesis and secretion of premembrane and envelope proteins by the chimeric plasmid of dengue virus type 2 and Japanese encephalitis virus. Virology, 306: 170-180.

Chen HW, Liu SJ, Liu HH, Kwok Y, Lin CL, Lin LH, Chen MY, Tsai JP, Chang LS, Chiu FF, Lai LW, Lian WC, Yang CY, Hsieh SY, Chong P, Leng CH. 2009. A novel technology for the production of a heterologous lipoprotein immunogen in high yield has implications for the field of vaccine design. Vaccine, 27: $1400-1409$.

Chen L, Ewing D, Subramanian H, Block K, Rayner J, Alterson KD, Sedegah M, Hayes C, Porter K, Raviprakash K. 2007. A heterologous DNA prime-Venezuelan equine encephalitis virus replicon particle boost dengue vaccine regimen affords complete protection from virus challenge in cynomolgus macaques. J Virol, 81: 11634-11639.

Chen R, Vasilakis N. 2011. Dengue - Quo tu et quo vadis? Viruses, 3: $1562-1608$.

Chowdhury DR, Angov E, Kariuki T, Kumar N. 2009. A potent malaria transmission blocking vaccine based on codon harmonized full length Pfs48/45 expressed in Escherichia coli. PLoS ONE, 4: e6352.

Churdboonchart V, Bhamarapravati, Futrakul NP. 1983. Crossed immunoelectrophoresis for the detection of split products of the third complement in dengue hemorrhagic fever. I. Observations in patients' plasma. Am J Trop Med Hyg, 32: 569-576.

Clyde K, Kyle JL, Harris E. 2006. Recent advances in deciphering viral and host determinants of dengue virus replication and pathogenesis. J Virol, 80: 11418-11431.

Cornet M. 1993. Dengue in Africa. Epidemiology of dengue and dengue hemorrhagic fever. Monograph on dengue/dengue hemorrhagic fever. Geneva: World Health Organization, 39-47.

Costa RL, Voloch CM, Schrago CG. 2012. Comparative evolutionary epidemiology of dengue virus serotypes. Infect Genet Evol, 12: 309-314.

Crabtree MB, Kinney RM, and Miller BR. 2005. Deglycosylation of the NS1 protein of dengue 2 virus, strain 16681: construction and characterization of mutant viruses. Arch Virol, 150: 771786.

Cummings DAT, Iamsirithaworn S, Lessler JT, McDermott A, Prasanthong R, Nisalak A, Jarman RG, Bruke DS, Gibbons RV. 2009. The impact of the demographic transition on dengue in Thailand: insights from a statistical analysis and mathematical modeling. PLoS Med, 6: e1000139.

Dash AP, Bhatia R, Kalra NL. 2012. Dengue in South-East Asia: an appraisal of case management and vector control. WHO dengue Bulletin, 36: 1-13.

da Silva Voorham JM. 2014. A possible fifth dengue virus serotype. Ned Tijdschr Geneeskd, 158: A7946.

Dimopoulos G. 2003. Insect immunity and its implication in mosquito-malaria interactions. Cell Microbiol, 5: 3-14.

Doherty RL, Westaway EG, Whitehead RH. 1967. Further studies of the aetiology of an epidemic of dengue in Queensland, 19541955. Med J Australia, 2: 1078-1080.

Dorji T, Yoon IK, Holmes EC, Wangchuk S, Tobgay T, Nisalak A. 2009. Diversity and origin of dengue virus serotypes 1, 2, and 3, Bhutan. Emerg Infect Dis, 15: 1630-1632.

English L, Chemali M, Duron J, Rondeau C, Laplante A, Gingras 
D, Alexander D, Leib D, Norbury C, Lippé R, Desjardins M. 2009. Autophagy enhances the presentation of endogenous viral antigens on MHC class I molecules during HSV-1 infection. Nat Immunol, 10: 480-487.

Etemad B, Batra G, Raut R, Dahiya S, Khanam S, Swaminathan S, Khanna N. 2008. An envelope domain III-based chimeric antigen produced in Pichia pastoris elicits neutralizing antibodies against all four dengue virus serotypes. Am J Trop Med Hyg, 79: $353-363$.

European Centre for Disease Prevention and Control (ECDC) bulletin. 2014. Dengue - Multistate (world) - Monitoring seasonal epidemics in Communicable Disease Threats Report.

Falgout B, Pethel M, Zhang YM, Lai CJ. 1991. Both nonstructural proteins NS2B and NS3 are required for the proteolytic processing of dengue virus nonstructural proteins. J Virol, 65: $2467-2475$.

Fiqueiredo LTM, Cavalcante SMB, Simões MC. 1990. Dengue serologic survey of school children in Rio de Janeiro, Brazil in 1986 and 1987. Bull Pan Am Health Organ, 24: 217-225.

Freedman DO, Weld LH, Kozarsky PE, Fisk T, Robins R, von Sonnenburg F, Keystone JS, Pandey P, Cetron MS, GeoSentinel Surveillance Network. 2006. Spectrum of disease and relation to place of exposure among ill returned travelers. N Engl J Med, 354: 119-130.

Gasperino J, Yunen J, Guh A, Tanaka KE, Kvetan V, Doyle H. 2007. Fulminant liver failure secondary to haemorrhagic dengue in an international traveller. Liver Int, 27: 1148-1151.

Goncalvez AP, Engle RE, St Claire M, Purcell RH, Lai CJ. 2007. Monoclonal antibody-mediated enhancement of dengue virus infection in vitro and in vivo and strategies for prevention. Proc Natl Acad Sci USA, 104: 9422-9427.

Graham H. 1903. The dengue: a study of its pathology and mode of propagation. J Trop Med, 6: 209-214.

Guabiraba R, Ryffel B. 2014. Dengue virus infection: current concepts in immune mechanisms and lessons from murine models. Immunology, 141:143-156.

Guard RW, Stallman ND, Weimers MA. 1984. Dengue in northern region of Queensland, 1981-1982. Med J Australia, 140: 765-9.

Gubler DJ. 1976. Variation among geographic strains of Aedes albopictus in susceptibility to infection with dengue viruses. Am J Trop Med Hyg, 25: 319-325.

Gubler DJ. 1989. Aedes aegypti and Aedes aegypti-borne disease control in the 1990s: top down or bottom up. Charles Franklin Craig Lecture. Am J Trop Med Hyg, 40: 571-578.

Gubler DJ, Clark GG. 1995. Dengue/dengue hemorrhagic fever: the emergence of a global health problem. Emerg Infect Dis, 1.

Gubler DJ. 1997. Dengue and dengue hemorrhagic fever: its history and resurgence as a global public health problem. In: Dengue and dengue hemorrhagic fever. Gubler DJ, Kuno G (eds). London: CAB International, pp. 1-22.

Gubler DJ. 2004. The changing epidemiology of yellow fever and dengue, 1900 to 2003: full circle? Comp Immunol Microbiol Infect Dis, 27: 319-330.

Gubler DJ. 2006. Dengue/dengue haemorrhagic fever: history and current status. Novartis Found Symp. 277: 3-16.

Guha-Sapir D, Schimmer B. 2005. Dengue fever: new paradigms for a changing epidemiology. Emerg Themes Epidemiol, 2: 1.

Guirakhoo F, Pugachev K, Arroyo J, Miller C, Zhang ZX, Weltzin R, Georgakopoulos K, Catalan J, Ocran S, Draper K, Monath TP. 2002. Viremia and immunogenicity in nonhuman primates of a tetravalent yellow fever-dengue chimeric vaccine: genetic reconstructions, dose adjustment, and antibody responses against wild-type dengue virus isolates. Virology, 298: 146-159.

Gupta N, Srivastav S, Jain A, Chaturvedi UC. 2012. Dengue in India. Indian J Med Res, 136: 337-390.
Guzman MG, Halstead SB, Artsob H, Buchy P, Farrar J, Gubler DJ, Hunsperger E, Kroeger A, Margolis HS, Martínez E, Nathan MB, Pelegrino JL, Simmons C, Yoksan S, Peeling RW. 2010. Dengue: a continuing global threat. Nat Rev Microbiol, 8: S7S16.

Guzman MG, Kouri GP, Bravo J, Soler M, Vasquez S, Santos M, Villaescusa R, Basanta P, Indan G, Ballester JM. 1984. Dengue haemorrhagic fever in Cuba. II. Clinical investigations. Trans $\mathrm{R}$ Soc Trop Med Hyg, 78: 239-241.

Guzman MG, Alvarez M, Rodriguez R, Rosario D, Vazquez S, Valds L, Cabrera MV, Kouri G. 1999. Fatal dengue hemorrhagic fever in Cuba, 1997. Int J Infect Dis, 3: 130-135.

Guzman MG, Kouri G, Valdes L, Bravo J, Alvarez M, Vazques S, Delgado I, Halstead SB. 2000. Epidemiologic studies on Dengue in Santiagode Cuba,1997. Am J Epidemiol, 152: 793-799.

Halstead SB, Shotwell H, Casals J. 1973a. Studies on the pathogenesis of dengue infection in monkeys. II. Clinical laboratory responses to heterologous infection. J Infect Dis, 128: 15-22.

Halstead SB, Shotwell H, Casals J. 1973b. Studies on the pathogenesis of dengue infection in monkeys. I. Clinical laboratory responses to primary infection. J Infect Dis, 128: 7-14.

Halstead SB. 2006. Dengue in the Americas and Southeast Asia: do they differ? Rev Panam Salud Publica, 6: 407-415.

Halstead SB. 2008. Dengue Virus-Mosquito Interactions. Annu Rev Entomol, 53: 273-291.

Halstead S, Thomas S. 2013. Dengue Vaccines. In: Dengue Vaccines. Plotkin S, Orenstein W and Offit P (eds). Elsevier: China, pp. 1042-1051.

Hammon WM, Rudnick A, Sather GE. 1960. Viruses associated with epidemic hemorrhagic fevers of the Philippines and Thailand. Science, 131: 1102-1103.

Heinz FX, Allison SL. 2003. Flavivirus structure and membrane fusion. Adv Virus Res, 59: 63-97.

Higa Y. 2011. Dengue Vectors and their Spatial Distribution. Trop Med health, 39: 11-27

Hirsch A. 1883. Dengue a comparatively new disease: its symptom. In: Handbook of geographical and historical pathology. Creighton C, editor. London: Sydenham Society, pp. 55-81.

Hotta S. 1957. Some immunological properties of dengue virus cultivated in tissue culture. Ann Trop Med Parasitol, 51: 249255.

Hsieh SC, Zou G, Tsai WY, Qing M, Chang GJ, Shi PY, Wang WK. 2011. The C-terminal helical domain of dengue virus precursor membrane protein is involved in virus assembly and entry. Virology, 410: 170-180.

Huang Q, Chen AS, Li Q, Kang C. 2011. Expression, purification, and initial structural characterization of nonstructural protein $2 \mathrm{~B}$, an integral membrane protein of dengue- 2 virus, in detergent micelles. Protein Expr Purif, 80: 169-175.

Hung SL, Lee PL, Chen HW, Chen LK, Kao CL, King CC. 1999. Analysis of the steps involved in Dengue virus entry into host cells. Virology, 257: 156-167.

Imoto J, Konishi E. 2007. Dengue tetravalent DNA vaccine increases its immunogenicity in mice when mixed with a dengue type 2 subunit vaccine or an inactivated Japanese encephalitis vaccine. Vaccine, 25: 1076-1084.

Ip YT. 2005. Drosophila innate immunity goes viral. Nat Immunol, 6: 863-864.

Isturiz RE, Gubler DJ, Brea del Castillo J. 2000. Dengue and dengue hemorrhagic fever in Latin America and the Caribbean. Infect Dis Clin North Am, 14: 121-140.

Jain B, Chaturvedi UC, Jain A. 2014. Role of intracellular events in the pathogenesis of dengue; an overview. Microb Pathog, 6970: 45-52.

Jessie K, Fong MY, Devi S, Lam SK, Wong KT. 2004. Localiza- 
tion of dengue virus in naturally infected human tissues, by immunohistochemistry and in situ hybridization. J Infect Dis, 189: 1411-1418.

Jessie K, Fong MY, Devi S, Lam SK, Wong KT. 2004. Localization of dengue virus in naturally infected human tissues, by immunohistochemistry and in situ hybridization. J Infect Dis, 189: 1411-1418.

John ALS, Abraham SN, Gubler DJ. 2013. Barriers to preclinical investigations of anti-dengue immunity and dengue pathogenesis. Nat Rev Microbiol, 11: 420-426.

Johnson AJ, Roehrig JT. 1999. New mouse model for dengue virus vaccine testing. J Virol, 73: 783-786.

Kangwanpong D, Bhamarapravati N, Lucia HL. 1995. Diagnosing dengue virus infection in archived autopsy tissues by means of the in situ PCR method: a case report. Clin Diagn Virol, 3: $165-172$.

Kay BH, Barker-Hudson P, Stallman ND, Wiemers MA, Marks EN, Holt PJ, Muscio M, Gorman BM. 1984. Dengue fever. Reappearance in northern Queensland after 26 years. Med J Australia, 140: 264-268.

Khanam S, Pilankatta R, Khanna N, Swaminathan S. 2009. An adenovirus type 5 (AdV5) vector encoding an envelope domain III-based tetravalent antigen elicits immune responses against all four dengue viruses in the presence of prior AdV5 immunity. Vaccine, 27: 6011-21.

King WW. 1917. The epidemic of dengue in the Porto Rico epidemic of 1915. New Orleans Med Surg J, 69: 564-571.

Knope K, Arbovirus N, Malaria Advisory Committee, Giele C. 2013. Increasing notifications of dengue in Australia related to overseas travel, 1991 to 2012. Commun Dis Intell Q Rep, 37: E55-E59.

Kochel TJ, Watts DM, Gozalo AS, Ewing DF, Porter KR, Russell KL. 2005. Cross-serotype neutralization of dengue virus in Aotus nancymae monkeys. J Infect Dis, 191: 1000-1004.

Koraka P, Benton S, van Amerongen G, Stittelaar KJ, Osterhaus AD. 2007. Characterization of humoral and cellular immune responses in cynomolgus macaques upon primary and subsequent heterologous infections with dengue viruses. Microbes Infect, 7: 940-946.

Kroschewski H, Lim SP, Butcher RE, Yap TL, Lescar J, Wright PJ, Vasudevan SG, Davidson AD. 2008. Mutagenesis of the dengue virus type 2 NS5 methyltransferase domain. J Biol Chem, 283: 19410-19421.

Kuhn RJ, Zhang W, Rossmann MG, Pletnev SV, Corver J, Lenches E, Jones CT, Mukhopadhyay S, Chipman PR, Strauss EG, Baker TS, Strauss JH. 2002. Structure of dengue virus: implications for flavivirus organization, maturation, and fusion. Cell, 108: 717-725.

Kurosu T, Chaichana P, Yamate M, Anantapreecha S, Ikuta K. 2007. Secreted complement regulatory protein clusterin interacts with dengue virus nonstructural protein 1. Biochem Biophys Res Commun, 362: 1051-1056.

Lambrechts L, Scott TW, Gubler DJ. 2010. Consequences of the expanding global distribution of Aedes albopictus for dengue virus transmission. PLoS Negl Trop Dis 4: e646.

Leng CH, Chen HW, Chang LS, Liu HH, Liu HY, Sher YP, Chang YW, Lien SP, Huang TY, Chen MY, Chou AH, Chong P, Liu SJ. 2010. A recombinant lipoprotein containing an unsaturated fatty acid activates NF-kappaB through the TLR2 signaling pathway and induces a differential gene profile from a synthetic lipopeptide. Mol Immunol, 47: 2015-2021.

Leng CH, Liu SJ, Tsai JP, Li YS, Chen MY, Liu HH, Lien SP, Yueh A, Hsiao KN, Lai LW, Liu FC, Chong P, Chen HW. 2009. A novel dengue vaccine candidate that induces cross-neutralizing antibodies and memory immunity. Microbes Infect, 11:
$288-295$

Li H, Clum S, You S, Ebner KE, and Padmanabhan R. 1999. The serine protease and RNA-stimulated nucleoside triphosphatase and RNA helicase functional domains of dengue virus type 2 NS3 converge within a region of 20 amino acids. J Virol, 73: 3108-3116.

Limon-Flores AY, Perez-Tapia M, Estrada-Garcia I, Vaughan G, Escobar-Gutierrez A, Calderon-Amador J, Herrera-Rodriguez AJ, Brizuela-Garcia A, Heras-Chavarria M, Flores-Langarica A, Cedillo-Barron L, Flores-Romo L. 2005. Dengue virus inoculation to human skin explants: an effective approach to assess in situ the early infection and the effects on cutaneous dendritic cells. Int J Exp Pathol, 86: 323-334.

Limonta D, Capo V, Torres G, Perez AB, Guzman MG. 2007. Apoptosis in tissues from fatal dengue shock syndrome. J Clin Virol, 40: 50-54.

Liu Y, Zhang F, Liu J, Xiao X, Zhang S, Qin C, Xiang Y, Wang P, Cheng G. 2014. Transmission-Blocking Antibodies against Mosquito C-Type Lectins for Dengue Prevention. PLoS Pathog, 10: e1003931.

Lumley GF. 1942. Dengue. Part 1. Medical. In: Dengue. Lumley GF, Taylor FH (eds). Sydney: University of Sydney and Commonwealth Department of Health, pp. 9-142.

Ma L, Jones CT, Groesch TD, Kuhn RJ, Post CB. 2004. Solution structure of dengue virus capsid protein reveals another fold. Proc Natl Acad Sci USA, 101: 3414-3419

Mackenzie JS, la Brooy JT, Hueston L, Cunningham AL. 1996. Dengue in Australia. J Med Microbiol, 45: 159-161.

Marchette NJ, Halstead SB, Falkler WA Jr, Stenhouse A, Nash D. 1973. Studies on the pathogenesis of dengue infection in monkeys. 3. Sequential distribution of virus in primary and heterologous infections. J Infect Dis, 128: 23-30.

Markiewski MM, Nilsson B, Ekdahl KN, Mollnes TE, Lambris JD. 2007. Complement and coagulation: strangers or partners in crime? Trends Immunol, 28: 184-192.

Martina BEE, Koraka E, Osterhaus ADME. 2009. Dengue virus pathogenesis: an integrated view. Clin Microbiol Rev, 22: 564 581.

McArthur JH, Durbin AP, Marron JA, Wanionek KA, Thumar B, Pierro DJ, Schmidt AC, Blaney JE Jr, Murphy BR, Whitehead SS. 2008. Phase I clinical evaluation of rDEN4Delta30-200, 201: a live attenuated dengue 4 vaccine candidate designed for decreased hepatotoxicity. Am J Trop Med Hyg, 79: 678-684.

McBride WJ, Mullner H, Muller R, Labrooy J, Wronski I. 1998. Determinants of dengue 2 infection among residents of Charters Towers, Queensland, Australia. Am J Epidemiol, 148: 11111116.

McLean DM, Magrath WJ. 1959. Dengue in the Northern Territory. Med J Australia, 46: 719-721.

Medlock JM, Hansford KM, Schaffner F, Versteirt V, Hendrickx G, Zeller H, Van Bortel W. 2012. A review of the invasive mosquitoes in Europe: ecology, public health risks, and control options. Vector Borne Zoonotic Dis, 12: 435-447.

Men R, Bray M, Clark D, Chanock RM, Lai CJ. 1996. Dengue type 4 virus mutants containing deletions in the 3 ' noncoding region of the RNA genome: analysis of growth restriction in cell culture and altered viremia pattern and immunogenicity in rhesus monkeys. J Virol, 70: 3930-3937.

Mercer J, Schelhaas M, Helenius A. 2010. Virus entry by endocytosis. Annual Review of Biochemistry, 79: 803-833.

Miagostovich MP, Ramos RG, Nicol AF, Nogueira RM, Cuzzi-Maya T, Oliveira AV, Marchevsky RS, Mesquita RP, Schatzmayr HG. 1997. Retrospective study on dengue fatal cases. Clin Neuropathol, 16: 204-208.

Miller S, Kastner S, Krijnse-Locker J, Buhler S, Bartenschlager 
R. 2007. The nonstructural protein 4A of dengue virus is an integral membrane protein inducing membrane alterations in a 2K-regulated manner. J Biol Chem, 282: 8873-8882.

Miura K, Keister DB, Muratova OV, Sattabongkot J, Long CA, Saul A. 2007. Transmission-blocking activity induced by malaria vaccine candidates Pfs $25 / \mathrm{Pvs} 25$ is a direct and predictable function of antibody titer. Malar J, 6: 107.

Modis Y, Ogata S, Clements D, Harrison SC. 2005. Variable surface epitopes in the crystal structure of dengue virus type 3 envelope glycoprotein. J Virol, 79: 1223-1231.

Mohammed HP, Ramos MM, Rivera A, Johansson M, Munoz-Jordan JL, Sun W, Tomashek KM. 2010. Travel-associated dengue infections in the United States, 1996 to 2005. J Travel Med, 17: $8-14$.

Monath TP. 1988. The Arboviruses: ecology and epidemiology. Yellow fever, vol. V. Boca Raton: CRC Press, pp. 139-231.

Moore CG, Cline BL, Tiben ER. 1978. Aedes aegypti in Puerto Rico environmental determinants of larval abundance and relation to dengue virus transmission. Am J Trop Med Hyg, 27: $1225-31$.

Mosier DE. 2000. Human xenograft models for virus infection. Virology, 271: 215-219.

Munoz-Jordan JL, Laurent-Rolle M, Ashour J, Martinez-Sobrido L, Ashok M, Lipkin WI, Garcia-Sastre A. 2005. Inhibition of alpha/ beta interferon signaling by the NS4B protein of flaviviruses. J Virol, 79: 8004-8013.

Munoz-Jordan JL, Sanchez-Burgos GG, Laurent-Rolle M, Garcia-Sastre A. 2003. Inhibition of interferon signaling by dengue virus. Proc Natl Acad Sci USA, 100: 14333-14338.

Murray NE, Quam MB, Wilder-Smith A. 2013. Epidemiology of Dengue: past, present and future prospects. Clin Epidemiol, 20: 299-309.

Mustafa MS, Rasotgi V, Jain S, Gupta V. 2015. Discovery of fifth serotype of dengue virus (DENV-5): A new public health dilemma in dengue control. Med J Armed Forces India, 71: 67-70.

Nakamura N, Arima Y, Shimada T, Matsui T, Tada Y, Okabe N. 2012. Incidence of dengue virus infection among Japanese travellers, 2006 to 2010. Western Pac Surveill Response J, 3: 39-45.

Nathan MB, Dayal-Drager R, Guzman M. 2009. Epidemiology, burden of disease and transmission. WHO. Dengue guidelines for diagnosis, treatment, prevention and control. New edition. Geneva: WHO, 1-21.

Neff JM, Morris L, Gonzalez-Alcover R, Coleman PH, Lyss SB, Negron H. 1967. Dengue fever in a Puerto Rican community. Am J Epidemiol, 86: 162-184.

Normile D. 2013. Surprising new dengue virus throws a spanner in disease control efforts. Science, 342: 415.

Nybakken GE, Nelson CA, Chen BR, Diamond MS, Fremont DH. 2006. Crystal structure of the West Nile virus envelope glycoprotein. J Virol, 80: 11467-11474.

Oliphant T, Nybakken GE, Engle M, Xu Q, Nelson CA, Sukupolvi-Petty S, Marri A, Lachmi BE, Olshevsky U, Fremont DH, Pierson TC, Diamond MS. 2006. Antibody recognition and neutralization determinants on domains I and II of West Nile Virus envelope protein. J Virol, 801: 12149-12159.

Onlamoon N, Noisakran S, Hsiao HM, Duncan A, Villinger F, Ansari AA, Perng GC. 2010. Dengue virus-induced hemorrhage in a nonhuman primate model. Blood, 115: 1823-1834.

PAHO. 2008. Number of reported cases of dengue and dengue hemorrhagic fever (DHF), Region of the Americas (by country and subregion) Washington: Pan American Health Organization.

Pandey BD, Rai SK, Morita K, Kurane I. 2004. First case of dengue in Nepal. Nepal Med Coll J, 6: 157-9.

Pant CP, Yasuno M. 1973. Field studies on the gonotrophic cycle of Aedes aegypti in Bangkok, Thailand. J Med Entomol. 10:
219-223.

Pham AM, Langlois RA, tenOever BR. 2012. Replication in cells of hematopoietic origin Is necessary for dengue virus dissemination. PLoS Pathog, 8: e1002465.

Phillips D, Pearce M, Weimers M, Blumke G. 1992. Dengue 2 infection in northern Queensland. Comm Dis Intell (Aust), 16: 192-193.

Press release, Sanofi Pasteur's dengue vaccine candidate successfully completes final landmark phase iii clinical efficacy study in Latin America, Lyon France, 3rd September, 2014. URL: http://goo.gl/hTizPj.

Pugachev K, Zhang Z, Myers G, Levenbook I, Draper K, Lang J, Ocran S, Mitchell F, Parsons M, Brown N,Brandler S, Fournier C, Barrere B, Rizvi F, Travassos A, Nichols R, Trent D, Monath T. 2004. Safety and efficacy of chimeric yellow fever-dengue virus tetravalent vaccine formulations in nonhuman primates. J Virol, 78: 4761-4775.

Purdy DE, Chang GJ. 2005. Secretion of noninfectious dengue virus-like particles and identification of amino acids in the stem region involved in intracellular retention of envelope protein. Virology, 333: 239-250.

Putnak R, Barvir DA, Burrous JM, Dubois DR, D'Andrea VM, Hoke CH, Sadoff JC, Eckels KH. 1996. Development of a purified, inactivated, dengue-2 virus vaccine prototype in Vero cells: immunogenicity and protection in mice and rhesus monkeys. J Infect Dis, 174: 1176-1184.

Rahman M, Rahman K, Siddque AK, Shoma S, Kamal AH, Ali KS, Nisaluk A, Breiman RF. 2002. First outbreak of dengue hemorrhagic fever, Bangladesh. Emerg Infect Dis, 8: 738-740.

Rajapakse S. 2011. Dengue shock. J Emerg Trauma Shock, 4: 120-127.

Ramanathan MP, Kuo YC, Selling BH, Li Q, Sardesai NY, Kim JJ, Weiner DB. 2009. Development of a novel DNA SynCon tetravalent dengue vaccine that elicits immune responses against four serotypes. Vaccine, 27: 6444-6453.

Ramos C, Sánchez G, Pando RH, Baquera J, Hernández D, Mota J, Ramos J, Flores A, Llausás E. 1998. Dengue virus in the brain of a fatal case of hemorrhagic dengue fever. J Neurovirol., 4: 465-468.

Raut CG, Deolankar RP, Kolhapure RM, Goverdhan MK. 1996. Susceptibility of laboratory-bred rodents to the experimental infection with dengue virus type 2. Acta Virol, 40: 143-146.

Raviprakash K, Wang D, Ewing D, Holman DH, Block K, Woraratanadharm J, Chen L, Hayes C, Dong JY, Porter K. 2008. A tetravalent dengue vaccine based on a complex adenovirus vector provides significant protection in rhesus monkeys against all four serotypes of dengue virus. J Virol, 82: 6927-6934.

Ritchie SA, Pyke AT, Hall-Mendelin S, Day A, Mores CN, Christofferson RC, Gubler DJ, Bennett SN, van den Hurk AF. 2013. An explosive epidemic of DENV-3 in Cairns, Australia. PLoS ONE, 8: e68137.

Rodenhuis-Zybert IA, Wilschut J, Smit JM. 2010. Dengue virus life cycle: viral and host factors modulating infectivity. Cellular and Molecular Life Sciences, 67: 2773-2786.

Rosen L. 1958. Experimental infection of new world monkeys with dengue and yellow fever viruses. Am. J Trop Med Hyg, 7: 406-410.

Rosen L, Roseboom LE, Gubler DJ, Lien JC, Chaniotis BN. 1985. Comparative susceptibility of mosquito species and strains to oral and parenteral infection with dengue and Japanese encephalitis viruses. Am J Trop Med Hyg, 34: 603-15.

Rothman AL. 2004. Dengue: defining protective versus pathologic immunity. J Clin Invest, 113: 946-951.

Rothman AL. 2011. Immunity to dengue virus: a tale of original antigenic sin and tropical cytokine storms. Nat Rev Immunol, 
11: 532-543.

Row D, Pearce H, Hapgood G, Sheridan J. 1993. Dengue and dengue haemorrhagic fever in Charters Towers, Queensland. Comm Dis Intell (Aust), 17: 182-183.

Rudnick A, Lim T W. Ireland J L. 1986. Dengue fever studies in Malaysia. Bulletin of the Institute for Medical Research Malaysia, 23: 1-241.

Russell RC, Lee DJ, Stanislas Y. 1984. Aedes aegypti (L.) (Diptera: Culicidae) in New South Wales. Gen Appl Entomol, 16: 9-16.

Sabchareon A, Lang J, Chanthavanich P, Yoksan S, Forrat R, Attanath P, Sirivichayakul C, Pengsaa K, Pojjaroen-Anant C, Chokejindachai W, Jagsudee A, Saluzzo JF, Bhamarapravati N. 2002. Safety and immunogenicity of tetravalent live-attenuated dengue vaccines in Thai adult volunteers: role of serotype concentration, ratio, and multiple doses. Am J Trop Med Hyg, 66: 264-272.

Sabchareon A, Lang J, Chanthavanich P, Yoksan S, Forrat R, Attanath P, Sirivichayakul C, Pengsaa K, Pojjaroen-Anant C, Chambonneau L, Saluzzo JF, Bhamarapravati N. 2004. Safety and immunogenicity of a three dose regimen of two tetravalentlive-attenuated dengue vaccines in five- to twelve-year-old Thai children. Pediatr Infect Dis J, 23: 99-109.

Sabin AB, Schlesinger RW. 1945. Production of immunity to dengue with virus modified by propagation in mice. Science, 101: 640-642.

Sabin AB. 1952. Research on dengue during World War II. Am J Trop Med Hyg, 1: 30-50.

San Martín JL, Brathwaite O, Zambrano B, Solórzano JO, Bouckenooghe A, Dayan GH, Guzmán MG. 2010. The epidemiology of dengue in the Americas over the last three decades: a worrisome reality. Am J Trop Med Hyg, 82: 128-135.

Sanchez V, Gimenez S, Tomlinson B, Chan PK, Thomas GN, Forrat R, Chambonneau L, Deauvieau F, Lang J, Guy B. 2006. Innate and adaptive cellular immunity in flavivirus-naive human recipients of a live-attenuated dengue serotype 3 vaccine produced in Vero cells (VDV3). Vaccine, 24: 4914-4926.

Sarkar JK, Chatterjee SN, Chakravarty SK. 1964. Haemorrhagic fever in Calcutta: some epidemiological observations. Indian J Med Res, 52: 651-659.

Scherer WF, Russell PK, Rosen L, Casals J, Dickerman RW. 1978. Experimental infection of chimpanzees with dengue viruses. Am J Trop Med Hyg, 27: 590-599.

Schlesinger RW, Gordon I, Frankel JW, Winter JN, Patterson PR, Dorrance WR. 1956. Clinical and serological response of man to immunization with attenuated dengue and yellow fever viruses. J Immunol, 77: 352-364.

Schlesinger RW. 1977. Dengue viruses. Virol Monogr, 16: 1-132.

Schmitz J, Roehrig J, Barrett A, Hombach J. 2011. Next generation dengue vaccines: A review of candidates in preclinical development. Vaccine, 29: 7276- 7284.

Shaio MF, Chang FY, Hou SC. 1992. Complement pathway activity in serum from patients with classical dengue fever. Trans $\mathrm{R}$ Soc Trop Med Hyg, 86: 672-675.

Sharp TW, Wallace MR, Hayes CG, Sanchez JL, DeFraites RF, Arthur RR, Thornton SA, Batchelor RA, Rozmajzl PJ, Hanson RK, et al. 1995. Dengue fever in U.S. troops during Operation Restore Hope, Somalia, 1992-1993. Am J Trop Med Hyg, 53: 89-94.

Shepard DS, Coudeville L, Halasa YA, Zambrano B, Dayan GH. 2011. Economic impact of dengue illness in the Americas. Am J Trop Med Hyg, 84: 200-207.

Shepard DS, Undurraga EA, Halasa YA. 2013. Economic and disease burden of dengue in Southeast Asia. PLoS Negl Trop Dis, 7: e2055
Simmons JS, St. John JH, Reynolds FHK. 1931. Experimental studies of dengue. Philippine J Sci, 44: 1-252.

Sirisena PD, Noordeen F. 2014. Evolution of dengue in Sri Lanka-changes in the virus, vector, and climate. Int J Infect Dis, 19: 6-12.

Smith GCE. 1956. A localized outbreak of dengue fever in Kuala Lumpur. Epidemiological and clinical aspects. Med J Malaya, 10: 289-303.

Souza-Neto JA, Sim S, Dimopoulos G. 2009. An evolutionary conserved function of the JAK-STAT pathway in anti-dengue defense. Proc Natl Acad Sci U S A., 106: 17841-17846.

Suharti C, van Gorp ECM, Setiati TE, Dolmans WM, Djokomoeljanto RJ, Hack CE, ten CH, van der Meer JWM. 2002. The role of cytokines in activation of coagulation and fibrinolysis in dengue shock syndrome. Thromb Haemost, 87: 42-46.

Sun W, Edelman R, Kanesa-Thasan N, Eckels KH, Putnak JR, King AD, Houng HS, Tang D, Scherer JM, Hoke CH Jr, Innis BL. 2003. Vaccination of human volunteers with monovalent and tetravalent live-attenuated dengue vaccine candidates. Am J Trop Med Hyg, 69: 24-31.

Sun W, Nisalak A, Gettayacamin M, Eckels KH, Putnak JR, Vaughn DW, Innis BL, Thomas SJ, Endy TP. 2006. Protection of rhesus monkeys against dengue virus challenge after tetravalent live attenuated dengue virus vaccination. J Infect Dis, 193: $1658-1665$.

Suttitheptumronga A, Khunchaia S, Panaampona J, Yasamuta U, Morchanga A, Puttikhuntd C, Noisakrand S, Haegemana G, Yenchitsomanusa P, Limjindaporn T. 2013. Compound A, a dissociated glucocorticoid receptor modulator, reduces dengue virus-induced cytokine secretion and dengue virus production. Biochem Biophys Res Commun, 436: 283-288.

Suzuki R, Winkelmann ER, Mason PW. 2009. Construction and characterization of a single-cycle chimeric flavivirus vaccine candidate that protects mice against lethal challenge with dengue virus type 2. J Virol, 83: 1870-80.

Tomashek KM, Rivera A, Muñoz-Jordan JL, Hunsperger E, Santiago L, Padro O, Garcia E, Sun W. 2009. Description of a large island-wide outbreak of dengue in Puerto Rico, 2007. Am J Trop Med Hyg, 81: 467-474.

Valdes I, Bernardo L, Gil L, Pavon A, Lazo L, Lopez C, Romero Y, Menendez I, Falcón V, Betancourt L, Martín J, Chinea G, Silva R, Guzmán MG, Guillén G, Hermida L. 2009a. A novel fusion protein domain III-capsid from dengue-2, in a highly aggregated form, induces a functional immune response and protection in mice. Virology, 394: 249-258.

Valdes I, Hermida L, Martin J, Menendez T, Gil L, Lazo L, Castro J, Niebla O, López C, Bernardo L, Sánchez J, Romero Y, Martínez R, Guzmán MG, Guillén G. 2009b. Immunological evaluation in nonhuman primates of formulations based on the chimeric protein P64k-domain III of dengue 2 and two components of Neisseria meningitidis. Vaccine, 27: 995-1001.

Valdes I, Gil L, Romero Y, Castro J, Puente P, Lazo L, Marcos E, Guzmán MG, Guillén G, Hermida L. 2011. The chimeric protein domain III-capsid of dengue virus serotype 2 (DEN-2) successfully boosts neutralizing antibodies generated in monkeys upon infection with DEN-2. Clin Vaccine Immunol, 18: 455-459.

Vasilakis N, Holmes EC, Fokam EB, Faye O, Diallo M, Sall AA, Weaver SC. 2007. Evolutionary processes among sylvatic dengue type 2 viruses. J Virol, 81: 9591-9595.

Vlaycheva LA, Chambers TJ. 2002. Neuroblastoma cell-adapted yellow fever 17D virus: characterization of a viral variant associated with persistent infection and decreased virus spread. J Virol, 76: 6172-6184.

Wahala WMPB, de Silva AM. 2011. The human antibody response 
to dengue virus infection. Viruses, 3: 2374-2395.

Wan S, Lin C, Wang S, Chen Y, Yeh T, Liu H, Anderson R, Lin YS. 2013. Current progress in dengue vaccines. J Biomed Sci, 20: 37.

Wang E, Ni H, Xu R, Barrett AD, Watowich SJ, Gubler DJ, Weaver SC. 2000. Evolutionary relationships of endemic/epidemic and sylvatic dengue viruses. J Virol, 74: 3227-3234.

Wei J, Chen H, An J. 2014. Recent progress in dengue vaccine development. Virol Sin, 29: 353-363.

Welsch S, Miller S, Romero-Brey I, Merz A, Bleck CK, Walther P, Fuller SD, Antony C, Krijnse-Locker J, Bartenschlager R. 2009. Composition and three-dimensional architecture of the dengue virus replication and assembly sites. Cell Host \& Microbe, 5: 365-375.

Were F. 2012. The dengue situation in Africa. Paediatrics and International Child Health, 32: 18-21.

White LJ, Parsons MM, Whitmore AC, Williams BM, de Silva A, Johnston RE. 2007. An immunogenic and protective alphavirus replicon particle-based dengue vaccine overcomes maternal antibody interference in weanling mice. J Virol, 81: 10329-10339.

Whitehead SS, Blaney JE, Durbin AP, Murphy BR. 2007. Prospects for a dengue virus vaccine. Nat Rev Microbiol, 5: 518-528.

Whitehead SS, Falgout B, Hanley KA, Blaney JE Jr, Markoff L Jr, Murphy BR. 2003. A live, attenuated dengue virus type 1 vaccine candidate with a 30 - nucleotide deletion in the $3^{\prime}$ untranslated region is highly attenuated and immunogenic in monkeys. J Virol, 77: 1653-1657.

Whitehorn J, Farrar J. 2010. Dengue. Br Med Bull, 95:161-173.

Wilder-Smith A, Gubler DJ. 2008. Geographic expansion of dengue: the impact of international travel. Med Clin N Am, 92: 1377-1390.

Wilder-Smith A, Ooi EE, Vasudevan SG, Gubler DJ. 2010. Update on dengue: epidemiology, virus evolution, antiviral drugs, and vaccine development. Curr Infect Dis Rep, 12: 157-164.

Wisseman CL, Sweet Jr BH, Rosenzweig EC. 1963. Attenuated living type 1 dengue vaccines. Am J Trop Med Hyg, 12: 620623.

Wiwanitkit S, Wiwanitkit V. 2015. Acute viral hemorrhage disease: A summary on new viruses. Journal of Acute Disease, doi:10.1016/j.joad.2015.06.004.

World Health Organization (WHO). 1999. Guidelines for Treatment of Dengue Fever / Dengue Haemorrhagic Fever in Small Hospitals. WHO Regional Office for South-East Asia Publication.

World Health Organization (WHO). 2012a. Global Strategy for Dengue Prevention and Control, 2012-2020. Geneva: WHO Press.

World Health Organization (WHO). 2012b. Handbook for Clinical Management of Dengue. WHO Press.

World Health Organization (WHO). 2012c. Handbook for Integrated Vector Management. WHO Press.

Xie X, Gayen S, Kang C, Yuan Z, Shi PY. 2013. Membrane topology and function of dengue virus NS2A protein. J Virol, 87: 4609-4622.

Yasuno M, Tonn RJ. 1970. A study of biting habits of Aedes aegypti in Bangkok, Thailand. Bull. WHO, 43: 319-25.

Yauch LE, Shresta S. 2008. Mouse models of dengue virus infection and disease. Antiviral Res, 80: 87-93.

Yazi MM, Salas-Benito JS, Lanz-Mendoza H, Hernandez-Martinez S, Del Angel RM. 2002. A putative receptor for dengue virus in mosquito tissues: localization of a $45-\mathrm{kDa}$ glycoprotein. Am J Trop Med Hyg, 67: 76-84.

Zompi S, Harris E. 2012. Animal models of dengue virus infection. Viruses, 4: 62-82. 